\title{
CONSTITUCIONES ECONÓMICAS DE ESTADOS UNIDOS Y ALEMANIA: LECCIONES PARA EL PERÚ
}

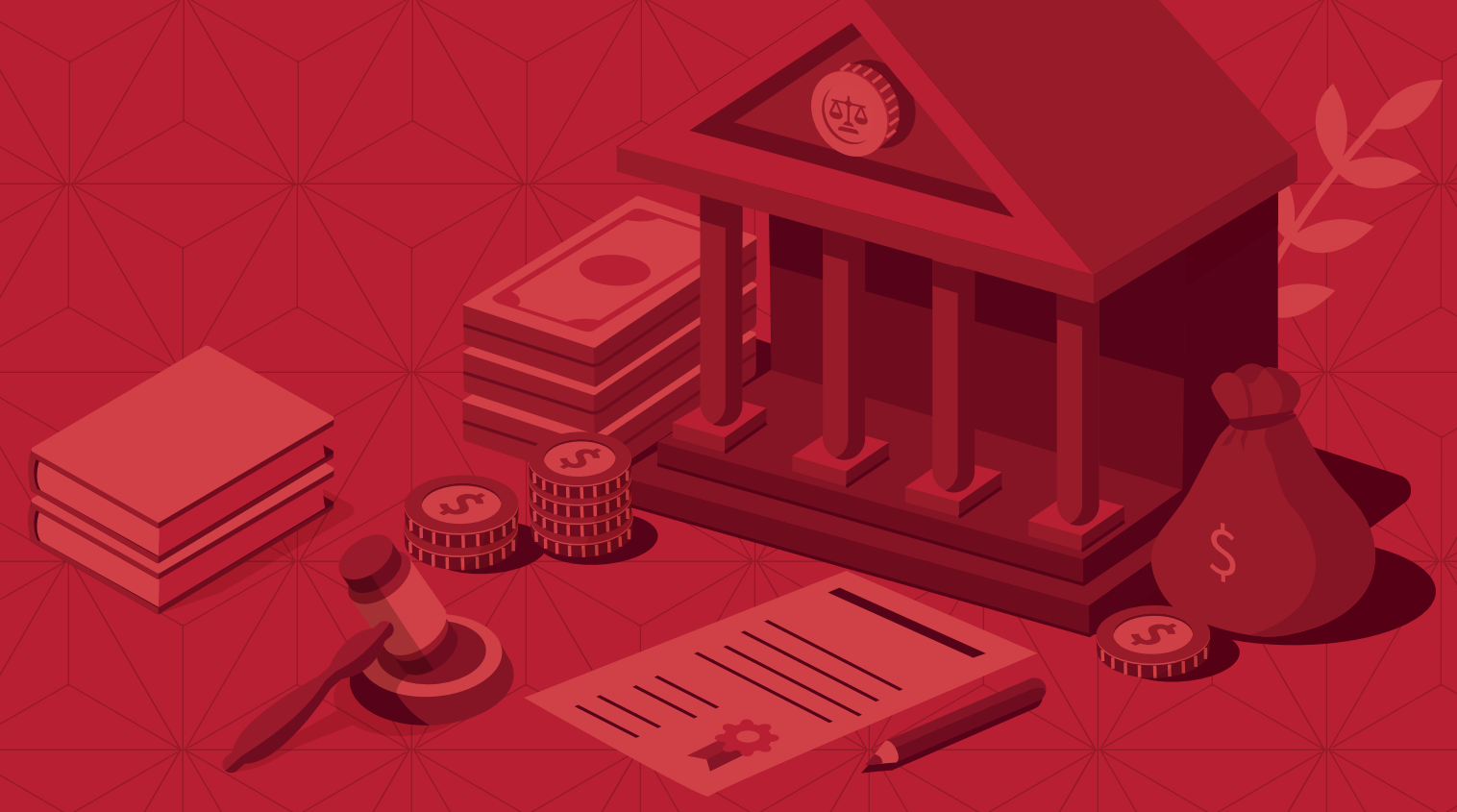

Edición y presentación:

Autores:
Braulio Arias Villagómez

Lucas Ghersi Murillo Mateo Salinas Fetzer

Facultad de

Derecho y

Ciencia Política 
Facultad de Derecho y Ciencia Política

Universidad Privada Norbert Wiener

\section{Constituciones Económicas de Estados Unidos y Alemania: Lecciones para el Perú}

Braulio Arias Villagomez (Ed.)

Lucas Ghersi Murillo Mateo Salinas Fetzer

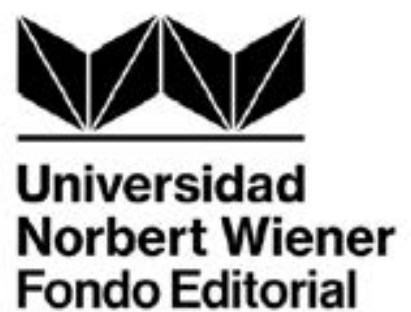


Primera edición, julio 2021

(c) 2021. Universidad Privada Norbert Wiener S.A.

Jr. Larrabure y Unanue 110. Urb. Santa Beatriz, Lima. Perú Contacto: facultad.derecho@uwiener.edu.pe www.uwiener.edu.pe

ISBN: 978-612-48657-0-1

DOI: https://doi.org/10.37768/unw.fdcp.00003

Prohibida su total o parcial reproducción por cualquier medio de impresión o digital en forma idéntica, extractada o modificada, en castellano o en cualquier otro idioma sin autorización expresa de la casa editorial. 
Lucas Ghersi Murillo: LL.M por The University of Chicago, Estados Unidos de América. Abogado por la Pontificia Universidad Católica del Perú, graduado con honores. Abogado en el Estudio Ghersi Abogados.

Mateo Salinas Fetzer: LL.M por la Johann Wolfgang Goethe-Universität Frankfurt am Main, Alemania. Abogado por la Universidad de Lima. Abogado asociado en Estudio Muñiz, Olaya, Meléndez, Castro, Ono \& Herrera, Abogados. 
C O N T E N I D O

Presentación.

El programa económico de la Constitución de los Estados Unidos

$6-24$

4

Constitución económica y economía social de mercado $25-41$ 
¿Tiene la participación del Estado en la economía un impacto positivo, negativo o neutral en la economía? Esta es una pregunta que en Perú ha tenido diversas respuestas en función al contexto histórico y la situación económica. El papel de la Constitución y, en general, del Derecho en el desarrollo económico de una nación es esencial. A través de un modelo económico reconocido por la Constitución Política de un Estado, se institucionalizan leyes y políticas públicas, lo que una nación entiende por desarrollo económico a fin de orientar la actividad del Estado hacia un sentido.

De esta manera, se fijan objetivos de crecimiento priorizando metas para generar bienestar económico y social, creando reglas claras para que las personas compitan en armonía en una economía libre de mercado y tutelando los derechos de los consumidores.

En el caso peruano, la Constitución Política de Perú de 1993 consagra el principio de subsidiariedad, el cual exige un rol mínimo de intervención en la economía y restringe la actividad económica que este pueda desarrollar. Sin embargo, para comprender de manera más detallada las actuales tendencias sobre Constitución económica en Perú y Latinoamérica, es vital remitirnos a la evolución de este fenómeno en los Estados Unidos de América y Alemania.

En ese sentido, la Facultad de Derecho y Ciencia Política de la Universidad Privada Norbert Wiener organizó de manera virtual la videoconferencia internacional "Constituciones económicas de Estados Unidos y Alemania: Lecciones para el Perú", impartido por los docentes Mg. Lucas Ghersi Murillo y Mg. Mateo Salinas Fetzer. En este espacio, los destacados ponentes reflexionan sobre la influencia del capítulo económico de las constituciones de Estados Unidos de América y Alemania en Perú y el mundo.

De esta manera, la primera parte del presente libro recopila las reflexiones del Mg. Luchas Ghersi Murillo que explica, como pese a no contar con un capítulo económico exclusivamente dedicado a dicho tema, la Constitución de los Estados Unidos de América sí contiene un conjunto de políticas económicas. Estas han influenciado en gran medida a que muchas constituciones del mundo garanticen mercados competitivos y libre de distorsiones significativas.

Por otro lado, la segunda parte, escrita por el Mg. Mateo Salinas Fetzer compila fundamentos teóricos de la Constitución económica alemana y la economía social de mercado. En su texto, se resalta como los principios de la economía social de mercado en Alemania ha mantenido una moneda estable, la apertura de los mercados al comercio internacional, la protección a la propiedad privada, entre otros logros de gran importancia para el Perú y países de la región.

No cabe duda de que el presente libro de memorias contribuirá de manera significativa a la reflexión y al debate. Dado los últimos acontecimientos, donde se discute pertinencia de efectuar cambios estructurales del capítulo económico del Perú, sobretodo por las consecuencias sufridas por la crisis económica y social producidas por la pandemia de la COVID-19.

Braulio Arias Villagómez

Secretario Académico de la Facultad de Derecho y Ciencia Política

de la Universidad Privada Norbert Wiener.

Editor 


\section{EL PROGRAMA ECONÓMICO DE LA CONSTITUCIÓN DE LOS ESTADOS UNIDOS}

\section{Autor: Lucas Ghersi Murillo}

\section{Resumen:}

El presente artículo explica cómo, pese a no contar con un capítulo económico exclusivamente dedicado a dicho tema, la Constitución de los Estados Unidos de América sí contiene dentro de sí ambicioso conjunto de políticas en materia económica que, a la larga, han contribuido en gran medida a que se desarrollen en ese país mercados competitivos y libre de distorsiones significativas.

Pese a su antigüedad y a su carácter inorgánico, la Constitución económica de los Estados Unidos es, probablemente, una de las principales fuentes del constitucionalismo económico en el resto del mundo $\mathrm{y}$ del derecho internacional en materia de inversiones y comercio.

Por todo ello, estudiar la parte económica de la Constitución de Estados Unidos es, sin duda alguna, un paso esencial para entender los fundamentos institucionales de toda sociedad próspera y libre. 


\section{Introducción.}

La Constitución de los Estados Unidos de América no cuenta formalmente con un capítulo económico. Sin embargo, ésta sí contiene un planteamiento económico que, sin lugar a dudas, contribuyó al establecimiento de un régimen de libre comercio - y, por tanto, a la consolidación de un mercado interno - entre los estados de la Unión.

Dicho fenómeno, ha sido ampliamente estudiado desde hace muchos años en los Estados Unidos de América. El profesor Charles W. Mc Curdy (1978, p. 631), por ejemplo, ha tenido la oportunidad de señalar lo siguiente sobre el particular:

El "secreto" del crecimiento económico americano, escribió el jurista inglés Sir Henry Maine en 1886, radica en la prohibición [constitucional] contra la imposición de aranceles a la mercancía que pasaba de un estado a otro. [...] Esto asegura al productor el comando de un mercado libre sobre un enorme territorio de vasta riqueza natural.

En similar medida, el profesor Dwight R. Lee (1987) ha declarado lo siguiente':

Es difícil discutir el éxito de la Constitución de los Estados Unidos. La historia de los Estados Unidos en las décadas siguientes a la ratificación de la Constitución, fue una de gobierno limitado y libertad individual, aumentos importantes en el tamaño de los Estados Unidos en términos de población y geografía, y un crecimiento sin precedentes del bienestar económico. [...] Las oportunidades creadas por el proceso de especialización e intercambio, hecho posible por un gobierno responsable y limitado, motivó una efusión de esfuerzo productivo que pronto transformó un área silvestre en una de las naciones más prósperas del mundo. El rol de la Constitución de Estados Unidos en esta transformación fue importante [...].

Sobre la base de lo anterior, el presente artículo tiene por objetivo pasar revista al proyecto económico de la Constitución de los Estados Unidos de América. Con ese fin en mente, se describirá, en primer lugar, la génesis del constitucionalismo norteamericano incidiendo, particularmente, en las circunstancias que dieron lugar al establecimiento de un mercado interno común en dicho país. Posteriormente, se realizará un examen pormenorizado de las disposiciones constitucionales que configuran el proyecto económico bajo análisis, y de la forma en que éstas han sido interpretadas y aplicadas por la Corte Suprema de los Estados Unidos.

\section{Antecedentes históricos.}

\subsection{Desarrollo del constitucionalismo escrito en Norteamérica.}

Los Estados Unidos de América son la cuna del constitucionalismo moderno. Si bien, el término Constitución - interpretado de manera lata - ha sido empleado frecuentemente y de manera ininterrumpida desde la antigüedad clásica. Es recién en el contexto de la Revolución Americana que éste adquiere las características con las que comúnmente se encuentra asociado en el discurso contemporáneo.

En efecto, es en el territorio de lo que luego se convertiría en los Estados Unidos de América, donde se redactaron las primeras constituciones escritas, destinadas a producir efectos jurídicos vinculantes sobre sus destinatarios.

Los efectos disruptivos de este desarrollo no deben ser subestimados. Antes de la Revolución Americana por Constitución se entendía, fundamentalmente, el conjunto de prácticas y tradiciones políticas que 
eran consideradas obligatorias en una comunidad política determinada. Así, una Constitución no era elaborada ex ante sino descubierta ex post a partir del análisis - esencialmente histórico - de las normas escritas, los precedentes judiciales y el derecho consuetudinario prexistente (Hayek, 1960 p. 57).

Incluso hoy, esa es la forma en que debemos entender cualquier referencia a la Constitución del Reino Unido o a la de países como Australia, Nueva Zelanda o Canadá que reproducen en gran medida las instituciones jurídicas y políticas británicas. En menor medida, otros Estados que no cuentan con una Constitución escrita, tales como Arabia Saudita e Israel, también se enmarcan en esta tradición cuyos orígenes se remontan a autores clásicos tales como Aristóteles o Plutarco.

La vasta mayoría de países en el mundo, sin embargo, se adhieren a la vertiente moderna del constitucionalismo inaugurada por las Colonias Norteamericanas; es decir, cuentan con constituciones escritas que producen efectos vinculantes, son justiciables y pueden ser modificadas por las fuerzas políticas siguiendo los procedimientos previamente establecidos para tal fin. Tan dominante es esta vertiente del constitucionalismo, que, a menudo, se afirma que países sin una Constitución escrita tales como el Reino Unido o Canadá no tienen Constitución.

Este proceso ciertamente se realizó de manera muy gradual. En efecto, sus orígenes se remontan al inicio del proceso de colonización inglesa de Norteamérica y guardan relación con el hecho de que ésta fue realizada, en su mayor parte, por un conjunto de corporaciones y empresarios particulares y no por la autoridad real.

De hecho, como señala el profesor William C. Morey, el primer antecedente directo de las constituciones nacionales escritas fue, desde el punto de vista formal, meramente el estatuto de una compañía comercial aprobado en $1612^{2}$ :

Este tercer estatuto de Virginia, así, erigió al London Trading Company en un cuerpo político organizado democráticamente, con poderes conferidos a un ejecutivo en jefe, un consejo y una asamblea, con plena autoridad para legislar y establecer una forma de gobierno para la colonia confiada a su cuidado.

El estatuto que se acaba de describir, poseía todos los elementos esenciales de una Constitución escrita. Estableció un marco de gobierno y distribuyó funciones ejecutivas, judiciales y legislativas. Era, sin embargo, solamente la constitución de una compañía comercial inglesa (Morey, 1891, p. 541).

Cuando, en 1624, el London Trading Company fue disuelta y Virginia pasó a organizarse como una colonia real, el diseño constitucional preexistente se mantuvo. Así, desde el punto de vista formal, el Estatuto de Virginia dejó de ser un documento corporativo convirtiéndose en una Constitución colonial sancionada por la autoridad real (Morey, 1891, p. 544).

El Estatuto de Virginia pronto se convirtió en un modelo empleado por los promotores de otras Colonias, para organizar políticamente a las comunidades que rápidamente venían estableciéndose allí. Al respecto, el profesor Morey comenta lo siguiente ${ }^{3}$ :

Virginia puede apropiadamente considerarse como el padre de las otras colonias del Sur. Sobre el territorio concedido a la London Company, luego se erigieron las colonias de Maryland y de las Carolinas; y la forma de gobierno otorgada por la ordenanza de 1621, se volvió el prototipo sobre la base del cual se modeló la de las demás colonias. Mientras la colonia de Virginia creció bajo el estatuto otorgado a una compañía comercial, y su Constitución estuvo definida

\footnotetext{
Fuente originalmente en inglés, traducción realizada por el autor.

Fuente originalmente en inglés, traducción realizada por el autor
} 
por una ordenanza de dicha compañía, las demás colonias sudistas crecieron bajo estatutos otorgados a sus propietarios, y sus constituciones fueron establecidas por las ordenanzas de esos propietarios, o por legislación popular. El punto a enfatizarse aquí, es el hecho de que las constituciones de las colonias con un propietario, pese a sus diferentes fuentes, se asimiló en la forma a la de Virginia, y de manera similar fueron establecidas por el Derecho escrito (Morey, 1891, p. 545).

No obstante ello, debe señalarse, tal y como se advierte a continuación, que la Constitución de Virginia no sólo inspiró la creación de gobiernos constitucionales en las Colonias del sur de los Estados Unidos; ésta también fue acogida como modelo en Nueva Inglaterra ${ }^{4}$ :

La Constitución de la Massachusetts Bay Company fue, así, sustancialmente idéntica a la de la London Company bajo su tercer estatuto y, consiguientemente, la misma forma de gobierno se convirtió en el prototipo político para las colonias, tanto en el Sur y en Nueva Inglaterra (Morey, 1891, p. 550).

De esa forma, queda claro que, incluso antes del estallido de la Revolución Americana, ya se había establecido firmemente, en lo que luego se convertiría en los Estados Unidos, una tradición de constitucionalismo escrito. Posiblemente, ello fue la consecuencia del hecho de que, en su mayoría, dichas constituciones fueron establecidas por corporaciones y/o por empresarios particulares. Es decir, se desarrollaron en un contexto mercantil donde, a diferencia de lo que ocurría en el constitucionalismo inglés, probablemente sí era necesario que las reglas de juego consten por escrito - por ejemplo, en el estatuto de una corporación - para poder ser oponibles a sus destinatarios (Howard, 2007, pp. 10-11).

Desde ese punto de vista, puede señalarse que el constitucionalismo escrito fue una consecuencia - probablemente no deseada - del origen iusprivatista de las colonias inglesas en Norteamérica. Así, la existencia política de dichas Colonias no dependía del derecho consuetudinario de Gran Bretaña sino de Constituciones escritas que, a menudo, fueron aprobadas de manera parcialmente democrática y establecieron también instituciones más o menos democráticas.

En ese sentido, es posible preguntarse hasta que punto la Revolución Americana fue realmente un intento por transformar radicalmente el status quo de las colonias norteamericanas. Ésta puede conceptualizarse, más bien, como un esfuerzo de dichas Colonias por preservar el autogobierno - basado en sus constituciones escritas - del que gozaban desde hace décadas, frente a una integración más directa al Imperio Británico que, en la segunda mitad del siglo XVIII, ya se encontraba en una posición de supervisar más de cerca el gobierno de sus territorios ultramarinos.

\subsection{Los artículos de la confederación.}

Por esa razón, en el contexto de la guerra para conquistar - o retener - su independencia frente al Reino Unido, las Colonias norteamericanas no buscaron inicialmente proclamar la existencia de una nueva nación soberana. Por el contrario, suscribieron los Artículos de la Confederación ${ }^{5}$, un instrumento jurídico que, pese a crear un Congreso común provisto de poderes limitados, señaló de manera expresa que cada una de las 13 colonias debía ser considerada un Estado plenamente independiente.

Los artículos II y III de dicho texto jurídico son meridianamente claros sobre el particular:

\footnotetext{
$4 \quad$ Fuente originalmente en inglés, traducción realizada por el autor.

Para consultar el texto de este instrumento jurídico en español, ver: https://web.archive.or g/web/20070807082947/ http://urquizadenis.com.ar/Documentos\%20Fundamentales\%20del\%20Constitucionalismo/Articulos_de_Confederacion_y_Union_Perpetua.htm.
} 
Artículo II

Cada estado retiene su soberanía, libertad e independencia y todo poder, jurisdicción o derecho que no es delegado expresamente por esta Confederación a los Estados Unidos, en Congreso reunido.

\section{Artículo III}

Los mencionados estados, por la presente, entran individualmente en una firme liga de amistad los unos con los otros, para su defensa común; la seguridad de sus libertades; y, su bienestar mutuo y general, obligándose a si mismos a asistirse los unos a los otros, contra toda fuerza opuesta a, o ataques realizados contra, ellos, o cualquiera de ellos, por motivos de religión, soberanía, comercio, o cualquier otro pretexto, cualquiera que éste sea.

Así, se evidencia que la naturaleza jurídica de los Artículos de la Confederación se asemeja más a la de un tratado internacional que a la de una Constitución. Como resulta evidente, este instrumento jurídico no tenía por finalidad establecer un nuevo Estado, sino instituir una liga entre las antiguas colonias inglesas, transformadas ahora en Estados independientes (Smith, 1997, p. 302).

En consecuencia, antes que configurarse como un texto propiamente constitucional, los Artículos de la Confederación son el antecedente histórico de los tratados que delegan determinadas competencias públicas a organizaciones supranacionales, tales como el Tratado de París de 1951 que creó la Comunidad Europea del Carbón y del Acero - precursora de la actual Unión Europea - o, inclusive, el Tratado de Cartagena de 1969, que constituyó la Comunidad Andina de Naciones.

En esos términos, podría argumentarse convincentemente que los Estados Unidos de América, tal y como éstos fueron organizados por los Artículos de la Confederación, se constituyeron como una de las primeras organizaciones internacionales jamás creadas formalmente mediante un tratado internacional.

Como sugiere el contexto en el que fueron aprobados, así como la redacción de su artículo III, los Artículos de la Confederación responden, fundamentalmente, a la lógica de una alianza militar impuesta - al menos parcialmente - por la necesidad. Puesto que las 13 Colonias de América del Norte se encontraban en ese momento librando una encarnizada guerra contra Gran Bretaña, resulta lógico que éstas buscarán establecer instituciones que les permitieran cooperar eficazmente entre si y, de esa manera, preservar su existencia como comunidades políticas autónomas. Ello ocurrió, posiblemente, sobre la base del ejemplo de las alianzas, establecidas entre polis griegas de la antigüedad clásica - sobre todo la Liga Aquea y la Liga Etólica - para hacer frente al poderío militar del Reino de Macedonia (Brice, 2015, p. 30).

Sin embargo, el proyecto contenido en los Artículos de la Confederación, no se limitó a establecer una alianza militar de carácter temporal o de emergencia. Por el contrario, planteó una iniciativa con vocación de permanencia que trascendió la coyuntura de la guerra contra Gran Bretaña (Freedman, 1978, p. 43).

El amplio alcance del programa político y económico del texto jurídico bajo análisis consta claramente en su artículo IV donde se señala lo siguiente:

Para mejor asegurar y perpetuar la amistad mutua y el intercambio entre las personas de los diferentes estados de esta Unión, los habitantes libres de cada uno de estos estados, exceptuando a los indigentes, vagabundos y fugitivos de la justicia, tendrán derecho a todos los privilegios e inmunidades de los ciudadanos libres de los diversos estados; y la gente de cada estado podrá ingresar y salir hacia y desde cualquier otro estado, y disfrutará allí de todos los privilegios del intercambio y del comercio, sujeto a los mismos 
derechos, imposiciones y restricciones que los habitantes de cada uno de los mismos respectivamente, siempre que tales restricciones no se extiendan hasta el punto de prevenir el retiro de propiedad importada a cualquier estado hacia cualquier otro estado, del cual su dueño sea habitante; siempre también que ninguna imposición, derecho a restricción sea impuesta por cualquier estado a la propiedad de los Estados Unidos o de cualquier otro estado.

Si cualquier persona culpable de, o acusada por, traición, delito u otras faltas graves en cualquier estado, escapara de la justicia y fuera encontrado en cualquiera de los Estados Unidos, será, ante el pedido del gobernador o del poder ejecutivo del estado del que huyó, entregado y removido al estado que tuviera jurisdicción sobre su ofensa.

Se dará plena fe y crédito en cualquiera de estos estados a los registros, actas y procedimientos de las cortes y magistrados de todo otro estado.

De lo anterior, queda claro que, si bien los Artículos de la Confederación no buscaron confundir permanentemente a los estados de la Unión entre sí, éstos sí generaron una intensa red de obligaciones recíprocas entre los mismos, varias de las cuáles poseían un intenso contenido económico.

En primer lugar, puede señalarse que, por mérito del artículo citado líneas arriba, cada uno de los estados de la Unión quedó obligado a tratar a los ciudadanos de todos demás estados de la misma manera que a sus propios nacionales. Así, los Artículos de la Confederación anticiparon la "cláusula de trato nacional", tan común en el derecho contemporáneo, tanto el rubro de las inversiones internacionales como en el del comercio internacional. En similar medida, el artículo bajo análisis estableció la obligación de los estados, de un lado, de extraditar a aquellas personas que fueran requeridas por la justicia de los demás estados. De otro lado, reconoce los registros y los fallos judiciales de sus pares.

En el cuarto párrafo del artículo IX del texto bajo análisis, a mayor abundamiento, se estableció expresamente lo siguiente:

Los Estados Unidos, en Congreso reunidos, tendrán también el único y exclusivo derecho y poder de regular la composición y el valor de la moneda acuñada por su propia autoridad, o por la de los respectivos estados - fijando los estándares de pesos y medidas en todos los Estados Unidos -; regular el comercio y manejar todos los asuntos con los indios, no miembros de ningún estado, siempre que el derecho legislativo de cualquier estado dentro de sus propias fronteras no sea infringido o vulnerado [...].

Esta disposición normativa es auténticamente revolucionaria. A través de ella, se le otorgó al Congreso de la Confederación el poder para regular el comercio presumiblemente de manera uniforme entre los distintos Estados de la Unión. Así, lo que aparenta ser una simple atribución de competencias al Congreso de la Unión, está dirigida, en el fondo, a establecer un mercado común entre los distintos Estados, eliminando la posibilidad de que éstos establezcan unilateralmente barreras al comercio a través de sus propias asambleas legislativas.

Dicha interpretación es plausible, no solo a la luz del desarrollo posterior del constitucionalismo norteamericano, sino también desde el punto de vista de la sistemática interna de los Artículos de la Confederación. En efecto, puesto que la atribución de poderes al Congreso para regular el comercio está regulada en el mismo artículo que la estandarización de pesos y medidas - una medida evidentemente dirigida a la creación de un mercado común - es posible inferir razonablemente que ésta también se encuentra dirigida a cumplir dicho objetivo.

De todo lo anterior, se evidencia que los Artículos de la Confederación contenían dentro de ellos un ambicioso proyecto económico destinado a consolidar el territorio de los Estados Unidos en una zona donde primara tanto la libertad de tránsito como la libertad de comercio. Al menos, esto se logró en lo 
referido a la ausencia de barreras arancelarias o de otras normas que discriminen entre los nacionales de un estado y los de uno o más de los doce restantes.

Sin embargo, por lo menos de acuerdo a la historiografía norteamericana del "mainstream", la posibilidad de que el programa económico de los Artículos de la Confederación se concrete se vio frustrada debido a la ausencia, de un lado, de un Poder Ejecutivo nacional dispuesto a hacer cumplir dichas normas y, de otro lado, de un sistema judicial federal capaz de adjudicar eficientemente las controversias que opongan a los estados de la Unión entre sí, o a uno de dichos estados con ciudadanos de otro estado ${ }^{6}$ (Freedman, 1978, pp. 142-143).

Bajo los Artículos de la Confederación, en efecto, el "Gobierno Central" - si es que cabe verdaderamente usar ese término - estaba compuesto únicamente por el Congreso de la Confederación y por el Ejército Continental dependiente de él. Todas las demás entidades y funciones públicas eran retenidas por los estados que, como se ha expuesto, eran reconocidos de manera expresa como naciones soberanas.

Probablemente, ello dio lugar, como ha señalado el profesor Jared Walczak, a que varios de los estados de la Unión hicieran caso omiso al texto expreso de los Artículos de la Confederación aprobando aranceles que gravaban la importación de bienes y/o servicios provenientes de otros estados (Walczak, 2016). Ello, a su vez, motivó el estallido de auténticas guerras comerciales entre estados ${ }^{7}$ :

A principios de 1787, las disputas estaban llegando a un punto crítico. Varios estados estaban burlando el espíritu y quizá la letra de los Artículos al imponer tarifas dirigidas a otros estados, y Nueva York llegó al extremo de imponer aranceles especiales de entrada y despacho a todos los navíos que se dirigían a o venían de Nueva Jersey o Connecticut. La Legislatura de New Jersey tomó represalias imponiendo un impuesto de treinta chelines mensuales a un faro que la ciudad de Nueva York había adquirido en Sandy Hook.

El estallido de disputas comerciales como la mencionada supra, en adición a otros factores que no cabe comentar aquí, dieron lugar al desarrollo de una crisis política aguda que, a su vez, motivó el proceso constituyente que se inició con la Convención de Annapolis de 1786 y culminó, después de gran controversia, con la ratificación de una Constitución en 1788.

La Constitución de los Estados Unidos transformaría la situación preexistente de manera definitiva dando lugar a la génesis de los Estados Unidos de América como una entidad soberana independiente que incorporó dentro de una estructura federal, a los 13 estados que lo precedieron.

\section{La Constitución económica de los Estados Unidos.}

\subsection{Algunas observaciones generales.}

Pese a transformar de manera radical el status político de las antiguas 13 Colonias, la Constitución de los Estados Unidos representa una continuación, y a la vez, un relanzamiento del proyecto económico desarrollado previamente por los Artículos de la Confederación.

A fin de advertir el grado en el que esto ocurre, debe tomarse en cuenta que las disposiciones de contenido explícitamente económico contenidas en la Constitución de los Estados Unidos son las que se indican a continuación ${ }^{8}$ : 


\section{Disposición constitucional de contenido económico}

Artículo 1.7.1: "Todo proyecto de ley que tenga por objeto la obtención de ingresos deberá proceder primeramente de la Cámara de Representantes; pero el Senado podrá proponer reformas o convenir en ellas de la misma manera que tratándose de otros proyectos".

Artículo 1.8.1: " El Congreso tendrá facultad: Para establecer y recaudar contribuciones, impuestos, derechos y consumos; para pagar las deudas y proveer a la defensa común y bienestar general de los Estados Unidos; pero todos los derechos, impuestos y consumos serán uniformes en todos los Estados Unidos."

Artículo 1.8.2: "(El Congreso tendrá facultad...) Para contratar empréstitos a cargo de créditos de los Estados Unidos."

Artículo 1.8.3: "(El Congreso tendrá facultad...) Para reglamentar el comercio con las naciones extranjeras, entre los diferentes Estados y con las tribus indias."

Artículo 1.8.4: "(El Congreso tendrá facultad...) Para establecer un régimen uniforme de naturalización y leyes uniformes en materia de quiebra en todos los Estados Unidos".

Artículo 1.8.5: "(El Congreso tendrá facultad...) Para acuñar monedas y determinar su valor, así como el de la moneda extranjera. Fijar los patrones de las pesas y medidas."

Artículo 1.8.7: "(El Congreso tendrá facultad...) Para establecer oficinas de correos y caminos de posta."

Artículo 1.8.8: " (El Congreso tendrá facultad...) Para fomentar el progreso de la ciencia y las artes útiles, asegurando a los autores e inventores, por un tiempo limitado, el derecho exclusivo sobre sus respectivos escritos y descubrimientos."

Artículo 1.9.5: "Ningún impuesto o derecho se establecerá sobre los artículos que se exporten de cualquier Estado".

\section{¿Existía una norma análoga en los Artículos de la Confederación?}

No. Los artículos de la Confederación no preveían ni una legislatura bicameral ni poderes tributarios a nivel central.

No. Sin embargo, si existió un antecedente. El primer párrafo del artículo 9 de los Artículos de la Confederación exigía a los distintos estados no discriminar en materia tributaria entre sus propios nacionales y de los de otros estados. Sin embargo, no se le otorgaba al Congreso Continental el poder para crear tributos.

No. Bajo los Artículos de la Confederación, el Congreso Continental no contaba con dicha facultad, sino que dependía de los distintos estados para llevar a cabo operaciones de ese tipo, como se señala expresamente en el quinto párrafo del artículo IX de dicho cuerpo normativo.

Sí. El cuarto párrafo del artículo IX de los Artículos de la Confederación otorgó una atribución similar al Congreso Continental.

No. Los artículos de la Confederación no preveían la existencia de regulación uniforme entre los estados en materia de naturalización o quiebras.

Sí. El cuarto párrafo del artículo IX de los Artículos de la Confederación otorgó un poder prácticamente idéntico al Congreso Continental.

Sí. El cuarto párrafo del artículo IX de los Artículos de la Confederación otorgó un poder prácticamente idéntico al Congreso Continental.

No. Los Artículos de la Confederación no contienen ninguna disposición que se refiera al derecho de propiedad intelectual.

Sí. Existe una disposición similar en el primer párrafo del artículo 4 de los Artículos de la Confederación.

\footnotetext{
vinculación con materia económicas, ni aquellas que se refieren de manera exclusiva al tráfico de esclavos, aún existente en aquella época. Asimismo, tampoco se toman en cuenta las disposiciones meramente transitorias o el artículo 1.9.4 de la Constitución que fue derogado por la decimosexta enmienda. Por su parte, sí se incluyen dentro de este análisis, las diez primeras enmiendas a la Constitución de los Estados Unidos, aprobadas poco después de la entrada en vigencia de dicho texto normativo, conocidas comúnmente como el "Bill of Rigths".
} 
Artículo 1.9.6: "Los puertos de un Estado no gozarán de preferencia sobre los de ningún otro a virtud de reglamentación alguna mercantil o fiscal; tampoco las embarcaciones que se dirijan a un Estado o procedan de él estarán obligadas a ingresar por algún otro, despachar en el sus documentos o cubrirle derechos."

Artículo 1.9.7: "Ninguna cantidad podrá extraerse del tesoro si no es como consecuencia de asignaciones autorizadas por la ley, y de tiempo en tiempo deberá publicarse un estado y cuenta ordenados de los ingresos y gastos del tesoro."

Artículo 1.10.1: "Ningún Estado celebrará tratado, alianza o confederación algunos; otorgará patentes de corso y represalias; acuñara moneda, emitirá papel moneda, legalizará cualquier cosa que no sea la moneda de oro y plata como medio de pago de las deudas; aprobará decretos por los que se castigue a determinadas personas sin que proceda juicio ante los tribunales, leyes ex post facto o leyes que menoscaben las obligaciones que derivan de los contratos, ni concederá título alguno de nobleza."

Artículo 1.10.2: "Sin el consentimiento del Congreso ningún Estado podrá imponer derechos sobre los artículos importados o exportados, cumplir sus leyes de inspección, y el producto neto de todos los derechos e impuestos que establezcan los Estados sobre las importaciones y exportaciones se aplicará en provecho del tesoro de los Estados Unidos; y todas las leyes de que se trata estarán sujetas a la revisión y vigilancia del Congreso."

Artículo 4.2.1: "Los ciudadanos de cada Estado tendrán derecho en los demás a todos los privilegios e inmunidades de los ciudadanos de estos."
Sí. El contenido normativo del primer párrafo del artículo IX de los Artículos de la Confederación engloba lo dispuesto por esta disposición constitucional.

No. Los Artículos de la Confederación no contemplan el principio de legalidad en materia presupuestaria. Por el contrario, el quinto párrafo del artículo IX de dicho cuerpo normativo señala que los gastos del gobierno central deben ser autorizados por un grupo parlamentario denominado "Comité de los Estados".

No. No existe una disposición normativa sustancialmente igual a esta en los Artículos de la Confederación. Sin embargo, sí se le otorga al Congreso Continental la facultad exclusiva de "regular el valor de la moneda" en el cuarto párrafo del artículo IX de dicho cuerpo normativo.

Si. El Contenido de esta disposición normativa está comprendido dentro de los dispuesto por el primer párrafo del artículo IV de los Artículos de la Confederación.

Sí. El contenido de esta disposición constitucional está incorporado, casi de manera literal, en el primer párrafo del artículo IV de los Artículos de la Confederación.
Quinta Enmienda: Nadie estará obligado a responder de un delito castigado con la pena capital o con otra infamante si un gran jurado no lo denuncia o acusa, a excepción de los casos que se presenten en las fuerzas de mar o tierra o en la milicia nacional cuando se encuentre en servicio efectivo en tiempo de guerra o peligro público; tampoco se pondrá a persona alguna dos veces en peligro de perder la vida o algún miembro con motivo del mismo delito; ni se le compela declarar contra sí misma en ningún juicio criminal; ni se le privará de la vida, la libertad o la propiedad sin el debido proceso legal; ni se ocupará la propiedad privada para uso público sin una justa indemnización.
No. Los Artículos de la Confederación no contemplaron ninguna disposición tendiente a resguardar a las personas frente a la expropiación arbitraria de su propiedad.

Sobre la base de lo anterior, pueden realizarse algunas observaciones que contribuyen a entender mejor el programa económico de la Constitución de los Estados Unidos.

Primera observación: De las 15 disposiciones constitucionales de contenido económico identificadas supra, 7 (aproximadamente el $47 \%$ del total) responden de manera muy clara a un antecedente 
contenido en los Artículos de la Confederación. Ello sugiere, como se ha expuesto, que el programa en materia económica de la Constitución de los Estados Unidos reproduce y amplía el de los Artículos de la Confederación.

Segunda observación: 13 de las 15 disposiciones constitucionales bajo análisis (aproximadamente el $87 \%$ del total), están incorporadas en el artículo 1 de la Constitución de los Estados Unidos, que establece las atribuciones del Poder Legislativo del Gobierno Federal. Ello revela un dato relevante sobre la técnica empleada por los padres fundadores de ese país para plasmar su programa económico y, de manera más general, sobre los presupuestos que subyacen al texto constitucional bajo análisis.

Así, en lugar de establecer exigencias y/o prohibiciones dirigidas directamente a los particulares y/o a los gobiernos de los diferentes Estados, las disposiciones constitucionales bajo examen inciden sobre el status jurídico de dichos sujetos de manera indirecta, en muchos casos, a través de normas que atribuyen competencias de manera exclusiva al Gobierno Federal.

Lo esencial aquí es advertir que, en el contexto en el que la Constitución de los Estados Unidos fue aprobada, otorgarle una competencia exclusiva al Gobierno Federal supone, contrario sensu, establecer una prohibición dirigida a los gobiernos de los diferentes estados de la Unión.

En consecuencia, atribuir este tipo de competencias al Gobierno Federal tiene por efecto establecer un ámbito normativo donde debe existir regulación uniforme al nivel de todos los estados de la Unión lo que, para estos efectos, tiende a generar un mercado común al interior del territorio de los Estados Unidos.

Tercera observación: De manera complementaria a lo anterior, puede señalarse que 7 de las 15 disposiciones constitucionales bajo comentario (aproximadamente el $47 \%$ del total) atribuyen competencias al Congreso de los Estados Unidos de América, lo que ratifica que dicho tipo de normas constituyen una parte muy significativa de la Constitución económica de los Estados Unidos de América.

Las demás disposiciones constitucionales objeto de análisis, a su vez, pueden clasificarse de la siguiente manera: normas que imponen obligaciones o mandatos al Congreso de los Estados Unidos de América: 3 de 15 (20\% del total); normas que imponen obligaciones a los estados de la Unión 3 de 15 (20\% del total), y, normas que reconocen derechos subjetivos: 2 de 15 (13\% del total aproximadamente).

Ello puede visualizarse con mayor claridad en el siguiente cuadro:

\begin{tabular}{|c|c|}
\hline \multicolumn{2}{|c|}{ Normas que conforman la Constitución económica de los Estados Unidos de América } \\
\hline \multicolumn{1}{|c|}{ Tipo de Norma } & Frecuencia \\
\hline Normas que establecen derechos subjetivos. & 2 de 15 (13\% del total aproximadamente). \\
\hline $\begin{array}{c}\text { Normas que establecen prohibiciones o imponen manda- } \\
\text { tos dirigidos al Gobierno Federal. }\end{array}$ & 3 de 15 (20\% del total). \\
\hline $\begin{array}{c}\text { Normas que establecen prohibiciones dirigidas, única o o } \\
\text { principalmente, a los gobiernos de los estados de la Unión. }\end{array}$ & 3 de 15 (20\% del total). \\
\hline $\begin{array}{c}\text { Normas que otorgan atribuciones al Congreso de los Es- } \\
\text { tados Unidos. }\end{array}$ & 7 de 15 (47\% del total, aproximadamente). \\
\hline
\end{tabular}


A continuación, se pasará revista a cada una de las disposiciones incluidas en dichas categorías a fin de obtener una noción, aunque sea panorámica, de cuál es el programa normativo en materia económica de la Constitución de los Estados Unidos.

\subsection{Panorama de la Constitución económica de los Estados Unidos.}

\subsubsection{Normas que establecen derechos subjetivos:}

\section{a. Artículo 4.2.1 de la Constitución de los Estados Unidos:}

Esta disposición constitucional, conocida comúnmente como la claúsula de privilegios e inmunidades, dispone que todos los ciudadanos de los Estados Unidos deben contar, en cada uno de los estados de la Unión, con los mismos derechos que éstos otorgan a sus propios ciudadanos.

Si bien esta norma no es aplicable de manera exclusiva a las relaciones de carácter comercial, es evidente que se extiende a ellas, de manera tal que puede considerársela, sin lugar a dudas, como parte de la Constitución económica de los Estados Unidos.

Como se recordará, los orígenes de esta disposición se remontan a los Artículos de la Confederación, en cuyo artículo IV, se preveía una norma sustancialmente idéntica a la que luego fue incorporada a la Constitución bajo análisis.

En lo que aquí resulta relevante, esta norma constitucional se configura como el equivalente de una "claúsula de trato nacional"; es decir, otorga a todos los estadounidenses el derecho a no ser objeto de tratamientos menos favorables que los concedidos a los nacionales de los estados en los que operan (Bogen, 1987, p. 836).

A nuestro juicio, esta norma constituye una de las piedras angulares de la Constitución de los Estados Unidos pues determina, si bien de manera indirecta, la imposibilidad de que los estados de la Unión aprueben normas destinadas a favorecer a sus nacionales, a costa de los demás estadounidenses contribuyendo, así, a la existencia de un mercado común al interior de dicho país ${ }^{9}$.

Tal es la importancia de esta disposición que, en El Federalista N. ${ }^{\circ} 80^{10}$ Alexander Hamilton señaló expresamente lo siguiente sobre el particular:

Puede considerarse la base de la Unión, que "Los ciudadanos de cada Estado tendrán derecho en los demás a todos los privilegios e inmunidades de los ciudadanos de los diversos estados. Y si es un principio justo que cada Gobierno debe poseer los medios para ejecutar sus propias disposiciones por su propia autoridad, se sigue que, para mantener inviolable la igualdad de privilegios e inmunidades a la que los ciudadanos de la Unión tendrán derecho, la judicatura nacional debe ser competente en todos los casos en los que un estado o sus ciudadanos se oponen a otro estado o sus ciudadanos. Para asegurar el efecto pleno de una disposición tan fundamental frente a toda evasión y subterfugio, es necesario que su interpretación sea confiada a aquel tribunal que, al no tener vinculaciones locales, será probable que sea imparcial (...) (énfasis agregado) (Hamilton, 1780).

Se evidencia, así, que esta disposición es un componente esencialísimo del constitucionalismo norteamericano. Ésta garantiza, en efecto, el derecho de todos los estadounidenses a acceder al mercado en cada uno de los estados de la Unión sin ser discriminado por mérito del estado de su origen o residencia. Ello ha sido confirmado por la jurisprudencia. En Supreme Court of New Hampshire v Piper (1985), por

\footnotetext{
9 Es importante tomar en cuenta en cuenta que, a lo largo de los años, la jurisprudencia ha reconocido algunas excepciones a esta regla tales como los derechos políticos y los derechos sobre recursos escasos no renovables. Ver, por ejemplo, Corfield v Coryell sobre el derecho a extraer ostras y almejas en Nueva Jersey (1823) o Geer v Connecticut sobre derechos de caza (1896)

10 Texto original en inglés, traducción realizada por el autor.
} 
ejemplo, se empleó la claúsula de privilegios e inmunidades para declarar inconstitucional una norma que restringía la capacidad de ejercer el derecho en el estado de New Hampshire a los residentes de ese estado. En Hickling v Orbeck (1979) y United Building and Construction Trade Council v Mayor of Camden (1984), a su vez, se declararon inconstitucionales leyes estatales que restringían, respectivamente, el derecho de los ciudadanos de otros estados a trabajar en la industria petrolera y a participar en licitaciones públicas.

Estos constituyen solo algunos ejemplos de la forma en la que esta disposición constitucional ha sido empleada a lo largo de los años para resguardar la existencia de un mercado común en los Estados Unidos de América.

\section{b. Quinta enmienda a la Constitución:}

La Quinta Enmienda a la Constitución de los Estados Unidos establece, en lo que aquí resulta relevante, que los poderes públicos no pueden privar a nadie de su propiedad para cumplir con una finalidad pública sin pagar compensación por el perjuicio que causan.

Sin lugar a dudas, esta disposición es un referente en el derecho constitucional comparado por ser, con toda probabilidad, una de las primeras normas escritas en reconocer de manera expresa un derecho a no ser objeto de confiscaciones. Así, ésta constituye un desarrollo, por ejemplo, respecto a la sección 39 de la Carta Magna que proscribe la posibilidad de que se lleven a cabo expropiaciones sin seguir el debido proceso legal (due process of law), pero no señala nada sobre la necesidad de pagar una indemnización justipreciada (Treanor, 2005, p. 10).

Esta norma constitucional, ha sido objeto tanto de una amplia literatura como de un abundante cuerpo de jurisprudencia. A nivel teórico, puede señalarse que tiene por objeto impedir que los funcionarios públicos lleven a cabo expropiaciones ineficientes, forzándolos a asumir el verdadero costo, de las mismas a fin de que no se utilice ese mecanismo para: (i) satisfacer necesidades o intereses privados, por ejemplo, expropiando a una persona para luego redistribuir su propiedad entregándosela a otra; o, (ii) satisfacer necesidades públicas cuyo valor es inferior al de las necesidades privadas que la propiedad expropiada satisfacía anteriormente (Levmore, 1991, pp. 1353-1354).

Algunos de los casos más connotados vinculados con este tema son Pennsylvania Coal Co. V Mahon (1922), First English Evangelical Lutheran Church v. Los Angeles County (1987) y Lucas v South Carolina Coastal Council (1992) mediante los cuales se determinó, respectivamente, que:

- Los derechos patrimoniales creados por la vía contractual, por ejemplo, el derecho a explotar un yacimiento de carbón, también pueden ser objeto de una expropiación.

- Se produce una expropiación, inclusive, si el Estado se apodera de la propiedad de un particular de manera transitoria.

- Se produce una expropiación si un Gobierno Local condiciona el usa de una propiedad inmueble a la donación de una parte sustancial de la misma para satisfacer una finalidad pública.

Esta norma constitucional, sobre la cual podría seguir ahondándose mucho más, no sólo constituye una parte esencial de la Constitución económica de los Estados Unidos sino también una fuente esencial para disposiciones similares que existen a nivel comparado y en materia del derecho de las inversiones internacionales.

\subsubsection{Normas que establecen prohibiciones o imponen mandatos dirigidos al Gobierno Federal.}

A diferencia de las disposiciones constitucionales comentadas líneas arriba, esta categoría de normas tiene un ámbito de aplicación más acotado. Sin perjuicio de ello, igual corresponde realizar un breve comentario sobre ellas, dada la importancia que tienen en el constitucionalismo norteamericano. 


\section{a. Artículo 1.7.1 de la Constitución de los Estados Unidos:}

Esta disposición constitucional, conocida comúnmente como origination clause, dispone que las iniciativas legislativas en materia tributaria sólo pueden originarse en la Cámara de Representantes y no en el Senado, como ocurre en la generalidad de los casos. Históricamente, esta norma es una manifestación de los compromisos políticos entre estados que permitió la ratificación de la Constitución de los Estados Unidos (Bagley y Smith, 2016).

A diferencia del Senado, donde cada estado de la Unión cuenta con dos representantes, la Cámara Baja otorga a los estados más populosos una delegación parlamentaria mayor y, por tanto, representa de manera más fidedigna a la población en general. Además, mientras el Senado originalmente estuvo compuesto por legisladores designados por el gobierno de cada estado, los representantes fueron electos desde un principio mediante el voto popular en la circunscripción correspondiente.

En consecuencia, queda claro la disposición bajo análisis busca garantizar que los proyectos de ley en materia tributaria se originen en la cámara legislativa que cuenta con mayor legitimidad democrática a fin de optimizar la máxima no taxation without representation, que fue tan importante para motivar la Revolución Americana.

\section{b. Artículo 1.9.6 de la Constitución de los Estados Unidos:}

Esta norma impone al Gobierno Federal el deber de no discriminar entre los puertos de los distintos estados de la Unión. En el contexto en el que se aprobó la Constitución, dicho asunto era de gran actualidad pues, en el siglo XVIII, era aún común que los Estados establecieran puertos privilegiados, que contaran con el monopolio del comercio internacional formal, entre otras razones, para poder centralizar la administración aduanera allí y, de esa forma, ahorrar fondos públicos (Pérez, 2013, p. 123).

Al imponer un deber de neutralidad al Gobierno Federal, esta norma probablemente permitió el desarrollo de la libre competencia en diversos mercados vinculados al comercio internacional. De esa forma, contribuyó a una mayor acumulación de riqueza, por lo menos, por una buena parte de la historia de los Estados Unidos.

La existencia de esta norma es un testimonio valioso de la actitud favorable a la libre competencia que subyace a la Constitución de los Estados Unidos.

\section{c. Artículo 1.9.7 de la Constitución de los Estados Unidos:}

Esta norma constitucional instituye, en el ordenamiento constitucional de Estados Unidos, lo que conocemos en nuestras latitudes como el principio constitucional de legalidad en materia presupuestaria. En efecto, el appropriations clause, como éste es comúnmente denominado, impone al Gobierno Federal la obligación de no realizar gasto público salvo que las erogaciones presupuestarias correspondientes hayan sido aprobadas mediante una ley aprobada por el Congreso.

Esta regla, como puede advertirse, es el reverso del principio de no taxation without representation. Si se requiere la participación de la legislatura, provista de legitimidad popular, para crear los tributos que se emplean para financiar el tesoro público, es lógico que también sea el Poder Legislativo el que autorice el gasto público, a fin de asegurar - al menos teóricamente - que éste se realice en beneficio de sus representados.

\subsubsection{Normas que establecen prohibiciones dirigidas (principalmente) a los estados de la Unión.}

La existencia de esta categoría de normas demuestra, contrariamente a lo que a menudo se piensa sobre la Constitución de los Estados Unidos, que este documento estuvo concebido desde un inicio como un instrumento jurídico vinculante no solo para el Gobierno Federal, sino también para los 
gobiernos estatales. Como se advertirá a continuación, estas disposiciones constitucionales están diseñadas, de manera muy clara, para resguardar la existencia de un mercado común en todo el territorio de la Unión.

\section{a. Artículo 1.9.5 de la Constitución de los Estados Unidos:}

Esta disposición constitucional prohíbe al Gobierno Federal, y a los gobiernos de los distintos estados, introducir impuestos que graven las exportaciones hacia el extranjero. La norma bajo análisis probablemente es, una vez más, el fruto de las negociaciones entre los estados en el marco del proceso constituyente de los Estados Unidos. En efecto, ésta disposición posiblemente surgió a fin de resguardar el interés de los estados con un sector agroexportador importante, temerosos de que otros estados impongan impuestos a sus nacionales por el uso de sus puertos.

Esta disposición constitucional ha tenido un desarrollo jurisprudencial en años relativamente recientes. Así, en United States v. IBM (1992), por ejemplo, se determinó que un impuesto al pago de primas a aseguradoras extranjeras resultaba inconstitucional por ser gravar exportaciones de manera indirecta. En United States v. United States Shoe Corp (1998), a su vez, se ordenó la inaplicación a los exportadores de un impuesto que grababa el $0.125 \%$ del valor comercial de todo el cargamento comercializado a través de los puertos de los Estados Unidos (Jensen, 2016).

\section{b. Artículo 1.10.1 de la Constitución de los Estados Unidos:}

En lo que aquí resulta relevante, esta norma prohíbe a los estados, de un lado, emitir moneda, y de otro lado, autorizar como medio de pago cualquier cosa distinta a las monedas de oro y plata o, presumiblemente, certificados representativos de las mismas.

Así, en su parte pertinente, esta disposición constitucional tiene por objeto, en primer lugar, asegurar la existencia de una unión monetaria en el territorio de los Estados Unidos lo que, como es evidente, contribuye al establecimiento de un mercado común en el territorio de la Unión. Esta norma también está dirigida a impedir que los diferentes estados emitan medios de pago, que no estén respaldados en monedas de oro y plata.

Ello a fin de evitar que se repitan los episodios inflacionarios, producidos durante la vigencia de los Artículos de la Confederación, como consecuencia de la emisión de certificados de crédito sin respaldo por los estados en los años inmediatamente posteriores a la Guerra de Independencia Norteamericana (Epstein y Rakove, 2016).

Adicionalmente, esta norma prohíbe a los gobiernos estatales aprobar leyes que "menoscaben las obligaciones que derivan de los contratos". Así, establece, por lo menos frente a los estados de la Unión, una garantía de intangibilidad de los contratos análoga a la regulada por el artículo 62 de la Constitución.

Desde el punto de vista histórico, esta norma es una reacción a diversas iniciativas, aprobadas durante la vigencia de los Artículos de la Confederación, a través de las cuáles las legislaturas estatales prorrogaban 0 , inclusive, exoneraban ciertas clases de deudas en las que habían incurrido sus nacionales (Epstein y Rakove, 2016).

\section{c. Artículo 10.1.2 de la Constitución de los Estados Unidos:}

Esta disposición es notable por la claridad con la que contribuye a materializar el programa económico de la Constitución de los Estados Unidos. Desde que prohíbe expresamente a los Estados imponer barreras arancelarias sin el consentimiento del Gobierno Federal, tiene por consecuencia producir una unión aduanera en el territorio de la unión impidiendo, así, que se reproduzcan algunos de los hechos que dieron lugar al colapso de los Artículos de la Confederación. 
La redacción de esta norma constitucional es tal que ésta debe entenderse referida tanto al comercio internacional como al comercio entre los estados de la Unión. Los casos que tienen que ver con este último supuesto, sin embargo, han sido evaluados por lo general a la luz del artículo 1.8.1 de la Constitución de los Estados Unidos.

\subsubsection{Normas que otorgan atribuciones al Congreso de los Estados Unidos.}

Como se ha señalado supra, esta categoría de normas - que, por demás, constituyen el grupo más numeroso de la Constitución económica bajo análisis - concretan el programa en materia económica de la Constitución de los Estados Unidos de manera indirecta.

Al atribuir competencias al Gobierno Federal, estas normas permiten que las materias bajo comentario sean reguladas de manera uniforme en todo el territorio de la Unión. Incluso si los diferentes estados poseyeran competencias concurrentes sobre algunos de dichos asuntos, ello no afecta la posibilidad de que se genere una regulación uniforme sobre el particular pues, según el artículo 6.2 de la Constitución bajo comentario (supremacy clause), las leyes federales prevalecen sobre las estatales ${ }^{11}$ :

Esta Constitución, y las leyes de los Estados Unidos que se expidan con arreglo a ella, y todos los tratados celebrados o que se celebren bajo la autoridad de los Estados Unidos, serán la suprema ley del país y los jueces de cada Estado estarán obligados a observarlos, a pesar de cualquier cosa en contrario que se encuentre en la Constitución o las leyes de cualquier Estado.

A continuación, se pasará revista, de manera muy breve, a las disposiciones constitucionales comprendidas dentro de esta categoría:

\section{a. Artículo 1.8.1 de la Constitución de los Estados Unidos:}

Esta norma, que establece la competencia del Congreso de los Estados Unidos para crear tributos, es una manifestación del principio de legalidad en materia tributaria que, en gran medida, inspiró la Revolución Americana de acuerdo con la máxima: no taxation without representation.

La disposición bajo análisis, por demás, constituye la otra cara de la moneda del artículo 10.1.2 de la Constitución, comentado supra. Desde que establece en forma expresa que todos los derechos (duties) deben ser uniformes en el territorio de la Unión, esta consagra con claridad la Unión Aduanera que existe en dicho territorio, especialmente si ésta se lee de manera sistemática con las demás normas constitucionales que se refieren a la materia.

Finalmente, desde el punto de vista histórico, debe considerarse que esta claúsula constitucional contrasta de manera marcada con el régimen existente bajo los Artículos de la Confederación, donde el Gobierno Central no poseía poder tributario alguno. Al contrario, dependía de transferencias realizadas por los estados, de manera similar a como ocurre con las organizaciones internacionales que, en la actualidad, son financiadas a través de sus miembros.

\section{b. Artículo 1.8.2 de la Constitución de los Estados Unidos:}

La disposición bajo análisis también se deriva de manera lógica de la máxima no taxation without representation. Si se requiere la participación del Congreso, en tanto asamblea provista con legitimidad democrática, tanto para autorizar el gasto público como para imponer tributos. En ese sentido, es natural que también sea necesaria dicha participación para llevar a cabo operaciones de endeudamiento, máxime si, a la larga, éstas suponen gasto público y, por tanto, tendrán que ser financiadas - casi con total seguridad - por los contribuyentes.

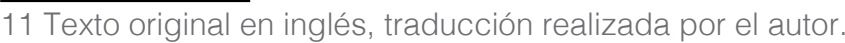




\section{c. Artículo 1.8.3 de la Constitución de los Estados Unidos:}

Esta disposición, conocida usualmente como el commerce clause, es una de las notas características de la Constitución económica bajo análisis y, además, uno de los asuntos que más discusión a generado tanto en la jurisprudencia como en la doctrina constitucional de los Estados Unidos. Por mérito de esta norma, es el gobierno federal, a través del Poder Legislativo, el que tiene la competencia para regular tanto el comercio internacional como el que se produce entre los diferentes estados de la Unión.

Como es natural, a lo largo de la historia, han existido prevalecido diferentes formas de interpretar esta norma constitucional. A lo largo del siglo XIX y las primeras décadas del siglo XX, por ejemplo, los tribunales estadounidenses entendieron que el poder otorgado al Congreso mediante esta cláusula para regular el comercio interestatal se circunscribía a aquellos casos en los cuales efectivamente se llevaban a cabo operaciones comerciales entre un estado y otro (Barnett y Koppelman, 2016).

A partir de la década de los 30 del siglo XX, sin embargo, comenzó a prevalecer una lectura más amplia de la cláusula en cuestión que le reconocía al Gobierno Federal la competencia para regular situaciones que pudieran incidir en el comercio inter-estatal, incluso si éstas no tenían carácter comercial o se producían exclusivamente al interior de un solo estado. Esta corriente jurisprudencial, acaso excesiva, empero, ha sido moderada en cierto grado a partir de United States v. Alfonso López Jr. (1995), caso en el cual la Corte Suprema de los Estados Unidos determinó - por 5 votos contra 4 - que la posesión de armas en escuelas no era una materia que podía considerarse propia del comercio interestatal. (Barnett y Koppelman, 2016).

Independientemente de ello, lo relevante para estos efectos es advertir que, a lo largo de su historia, los organismos jurisdiccionales de Estados Unidos han empleado esta cláusula de manera sistemática para declarar inconstitucionales las normas emitidas por los estados de la Unión. De alguna manera, esto menoscaba la existencia de un mercado común o generen barreras no arancelarias lesivas a la libre competencia.

Así, en el emblemático caso Gibbons v Ogden (1824), la Corte Suprema de los Estados Unidos declaró inconstitucional una norma emitida por Nueva York que otorgaba a un particular el monopolio de la navegación fluvial en todas las aguas de dicho estado. Dicha línea jurisprudencial fue mantenida a lo largo del siglo XIX, reiterada en el siglo XX y parte del derecho constitucional norteamericano incluso en nuestros días.

En Dean Milk Co. v City of Madison, Wisconsin (1951), Hunt v. Washington State Apple Advertising Commission (1977), City of Philadelphia v New Jersey (1978) y Tennessee Wine and Spirits Retailers Association v. Thomas (2019) se declararon inconstitucionales, normas estatales que, respectivamente, prohibían la venta de leche salvo que ésta hubiera sido pasteurizada en el estado de Wisconsin, impedía a la asociación de productores de manzanas de Washington hacer publicidad en Carolina del Norte, restringía la importación de chatarra al estado de New Jersey y prohibía la obtención de licencias para operar licorerías en Tennessee a quienes tuvieran menos de dos años de residencia en dicho estado.

Sobre esa base, queda claro que, en la práctica, esta disposición constitucional es empleada sistemáticamente por la justicia federal para dejar sin efecto los intentos de los Estados por menoscabar el mercado común mediante medidas discriminatorios o restrictivas de la libre competencia.

\section{d. Artículo 1.8.4 de la Constitución de los Estados Unidos:}

Este artículo otorga de manera expresa, a favor del Congreso de los Estados Unidos, la potestad de legislar de manera uniforme en todo el país en materia de quiebras. Ello, como es evidente, también coadyuva al establecimiento de un mercado común en dicho país. 


\section{e. Artículo 1.8.5 de la Constitución de los Estados Unidos:}

Esta norma, que otorga al Congreso Federal el poder para emitir moneda y determinar su valor, debe leerse sistemáticamente con el artículo 1.10 .1 de la Constitución que prohíbe a los estados llevar a cabo dichas competencias. Evaluadas de manera conjunta, ambas disposiciones establecen una unión monetaria en el territorio de los Estados Unidos y, de esa forma, contribuyen a la formación de un mercado común allí.

\section{f. Artículo 1.8.7 de la Constitución de Estados Unidos:}

En virtud de los dispuesto en esta norma, el Poder Legislativo federal posee la competencia establecer oficinas de correos y caminos de posta. Dicha atribución, como es evidente, está dirigida a reducir costos de transacción permitiendo que sea el Gobierno Central y no los distintos gobiernos estatales quienes se encarguen de desarrollar dichas redes en materia de infraestructura.

\section{g. Artículo 1.8.8 de la Constitución de Estados Unidos:}

Finalmente, esta disposición constitucional - verdaderamente innovadora para la época en la que fue emitida - faculta al Congreso Federal para legislar, en materia de propiedad intelectual e industrial, otorgando monopolios legales temporales a los inventores o autores según sea el caso, respecto de sus obras o descubrimientos. Dicha norma también contribuye a fortalecer la existencia de un mercado común en los Estados Unidos pues garantiza la existencia de regímenes uniformes en materia de propiedad intelectual e industrial en el país.

\section{Conclusiones.}

Sobre la base de todo lo anterior, puede advertirse que, pese a no contar con un capítulo económico, la Constitución de los Estados Unidos contiene dentro de sí un ambicioso conjunto de políticas en materia económica que, posiblemente, han contribuido en gran medida a que se desarrollen en ese país mercados competitivos y libres de distorsiones significativas.

Como puede advertirse, la Constitución económica de los Estados Unidos busca reducir costos de transacción garantizando que, una cantidad nada despreciable de materias (quiebras, propiedad intelectual e industrial, regulación del comercio interestatal, etc.), sean objeto de reglas uniformes a nivel de toda la Unión lo cual, por cierto, resulta excepcional en un Estado federal.

A ello hay que agregar que, por mérito de lo dispuesto en la Constitución, los Estados Unidos cuentan con una unión tanto monetaria como aduanera que configura, dentro de ese país, un mercado común de vastas proporciones. De otro lado, ésta también establece un conjunto de reglas y principios que, a lo largo de los años, han permitido a Estados Unidos librarse de numerosas restricciones al comercio de carácter discriminatorio y/o proteccionista.

Pese a su antigüedad y a su carácter inorgánico, la Constitución económica de los Estados Unidos es, probablemente, una de los principales fuentes del constitucionalismo económico en el resto del mundo y del derecho internacional en materia de inversiones y comercio. Por todo ello, estudiar la parte económica de la Constitución de Estados Unidos es, sin duda alguna, un paso esencial para entender los fundamentos institucionales de toda sociedad próspera y libre. 


\section{Bibliografía:}

Bagley, Nicholas y Smith, Thomas (2016), Article I, Section 7, Interactive Constitution, National Constitution Center. Disponible en: https://constitutioncenter.org/interactive-constitution/ interpretation/article-i/clauses/766. Consulta realizada el 19 de febrero de 2021.

Barnett, Randy E. y Koppelman, Andrew (2016), The Commerce Clause. Interactive Constitution, National Constitution Center. Disponible en: https://constitutioncenter.org/interactiveconstitution/interpretation/article-i/clauses/752. Consulta realizada el 19 de febrero de 2021.

Bogen, David S. (2017), The Privileges and Immunities Clause of Article IV, Case Western Reserve Law Journal, Volume 37, Issue 4, pp. 794-861 (1987). Disponible en: https://core.ac.uk/ download/pdf/214086404.pdf). Consulta realizada el 19 de febrero de 2021.

Brice, Shamir (2015), A Classy Constitution: Classical Influences on the United States Constitution from AncientGreekandRomanHistoryandPoliticalThought,SeniorHonorsProjects85, JohnCarrol University. Disponible en: https://collected.jcu.edu/cgi/viewcontent.cgi?referer=https:// www.google.com/\&httpsredir $=1 \&$ article $=1084 \&$ context=honorspapers.

Consulta realizada el 19 de febreo de 2021.

Epstein, Richard A. y Rakove, Jack (2016), Article I, Section 10, Interactive Constitution, National Constitution Center. Disponible en: https://constitutioncenter.org/interactive-constitution/ interpretation/article-i/clauses/767. Consulta realizada el 19 de febrero de 2021.

Freedman, Eric M. (1978), The United States and the Articles of Confederation: Drifting Towards Anarchy or Inching Towards Commonwealth. Yale Law Journal 142, Vol 88, pp. 142- 166. Disponible en: https://scholarlycommons.law.hofstra.edu/cgi/viewcontent. cgi?article=1811\&context=faculty_scholarship. Consulta realizada el 19 de febrero de 2021.

Hamilton, Alexander (1780), Federalist N 80, Yale Law School, Lilian Goldman Law Library, Avalon Project, Documents in Law History and Diplomacy. Disponible en: https://avalon.law.yale. edu/18th_century/fed80.asp. Consulta realizada el 19 de febrero de 2021.

Hayek, Friedrich A (1960), The Constitution of Liberty, The University of Chicago Press, Chicago.

Howard, AE. Dick, The Bridge of Jamestown: The Virginia Charter of 1606 and Constitutionalism in the Modern World, University of Richmond Law Review, Volume 42, Article 3, pp. 9-36. Disponible en: https://core.ac.uk/download/pdf/232792534.pdf. Consulta realizada el 19 de febrero de 2021.

Jensen, Erick M. (2016), Export and Port Preference Clauses, Interactive Constitution, National Constitution Center. Disponible en: https://constitutioncenter.org/interactive-constitution/ interpretation/article-i/clauses/758. Conuslta realizada el 19 de febrero de 2021.

Lee, Dwight, (1987). The Political Economy of the US Constitution, Foundation for Economic Education. Disponible en: https://fee.org/articles/the-political-economy-of-the-us-constitution/. Consulta realizada el 19 de febrero de 2021.

Levmore, Saul, (1991). Takings, Torts and Special Interests, Virginia Law Review, Issue 77, pp. 13331368. Disponible en: https://core.ac.uk/download/pdf/234136312.pdf. Consulta realizada el 19 de febrero de 2021. 
Mc Curdy, Charles, (1978). American Law and the Marketing Structure of the Large Corporation, The Journal of Economic History, Vol. XXXVIII, Number 3.

Morey, William C, (1891). The Genesis of a Written Constitution, The Annals of the American Academy of Political and Social Science, Vol 1, pp. 529-557. Disponible en: https://www.jstor.org/ stable/pdf/1008946.pdf. Consulta realizada el 19 de febrero de 2021.

Pérez de Arce Molina, Ricardo, (2013). La libertad de comercio y el monopolio comercial: los principios y normas constitucionales en el tránsito hacia la república y las proclamas de independencia, Revista de Derecho 19, Universidad de San Sebastián (Chile) pp. 115133.

Smith, Douglas G, An Analysis of Two Federal Structures: the Articles of Confederation and the Constitution, San Diego Law Review, Vol 34, pp. 249- 342 (1997). Disponible en: https:// digital.sandiego.edu/cgi/viewcontent.cgi?article=3066\&context=sdlr. Consulta realizada el 19 de febrero de 2021.

Treanor, Willia Michael, The Original Understanding of the Takings Clause, Georgetown Enviornmental Law and Policy Institute Papers and Reports (2010). Disponible en:https://scholarship. law.georgetown.edu/cgi/viewcontent.cgi?article=1001\&context=gelpi_papers. Consulta realizada el 19 de febrero de 2021.

Walczak, Jared, (2016). How Failed Tax Policy Led to the Constitutional Convention, Tax Foundation. Disponible en: https://taxfoundation.org/constitution-day-tax-policy-constitutionalconvention/. Consulta realizada el 19 de febrero de 2021. 


\section{CONSTITUCIÓN ECONÓMICA Y ECONOMÍA SOCIAL DE MERCADO}

\section{Autor: Mateo Salinas Fetzer}

\section{Resumen:}

El presente artículo se divide en dos partes. En la primera parte revisamos los fundamentos teóricos de la Constitución económica desde una perspectiva compatible con el programa de la economía social de mercado (ESM) que facilita el entendimiento de la lógica que subyace a esta institución. Se desarrolla una perspectiva del Constitucionalismo como límite del poder que resulta coherente con el principio de subsidiariedad que busca dar prevalencia a las iniciativas económicas desde la sociedad civil en oposición al planeamiento central estatal.

Desarrollamos las nociones fundamentales de autonomía privada, supremacía de la Ley y economía de mercado y desarrollamos la tesis que sustenta que la vigencia de la ESM depende en última línea del respeto de la esfera del autogobierno privado. En la segunda parte, abordamos la experiencia histórica del surgimiento de la ESM de mercado en la Alemania de la posguerra y los principios fundamentales que los teóricos y políticos alemanes establecieron como guía para este programa económico. 


\title{
Parte I: Fundamentos teóricos:
}

\begin{abstract}
"El respeto por el ser humano en cuanto tal -con su reflejo en derechos, libertades y prosperidad- pasa por reducir la coacción a estrictos mínimos, haciendo de cada uno señor supremo en su esfera privada. La experiencia nos indica, además, que dicho respeto despliega las alas al comercio, la industria y la ciencia en grado inaudito, y que ese camino -iniciado en Europa hace unos cinco siglos- no puede despojarse de espontaneidad sin despojarse de vitalidad".
\end{abstract}

Antonio Escohotado ${ }^{12}$.

Este trabajo fue preparado a raíz de un conversatorio académico respecto de la institución de la Constitución económica. En dicha ocasión, abordamos el surgimiento de la ESM como programa económico en la República Federal Alemana de la posguerra y comentamos sobre sus principios guía. Dado que, desde hace un tiempo, tenemos abierta en nuestro país la discusión pública respecto del asunto de la Constitución económica parece ser útil el repaso de algunas nociones fundamentales que colaboren a esclarecer la lógica de esta institución.

En la teoría jurídica nacional se han identificado dos concepciones distintas sobre la Constitución económica. Por un lado, explica Vignolo, hay referencias a este término como es comúnmente aceptado en la mayoría de los países hispanoamericanos, es decir, como

un conjunto articulado de normas jurídico-constitucionales que hacen alusión a la economía; reglas sistematizadas por los Constituyentes que tienen por finalidad "la de indicar cuáles han de ser los principios rectores de la actividad económica que habrán de desarrollar conjuntamente tanto los particulares como el Estado." (Gimeno Feliú citado por Vignolo, 2019, p.120).

Se aprecia que el énfasis de esta perspectiva se concentra en el designio y la voluntad del Constituyente en establecer explícitamente estos principios, y su carácter obligatorio al estar consagrados en la Constitución. Todo esto es de primera importancia, pero ayuda poco a mejorar nuestra comprensión de su funcionamiento y de su interdependencia de otros conceptos constitucionales fundamentales.

Por otro lado, el autor contrasta esta perspectiva con lo expuesto por el profesor Hakansson cuya "postura solitaria" consiste en afirmar que, si "las cartas magnas reconocen la igualdad, el derecho de propiedad y la libertad, y hay jueces independientes para protegerlos en todas sus formas [...] no creo que sea necesario dedicar un capítulo especial para esta materia" (Hakansson, 2019, p. 478).

Lo dicho por Hakansson nos permite entrever que la Constitución económica depende, en última instancia, de la observancia práctica o vigencia de principios constitucionales fundamentales como 
la libertad individual, la autonomía privada y el respeto de la propiedad y el contrato. En la primera parte de este trabajo nos interesa adentrarnos en los fundamentos de esta posición y explicar cómo es qué la Constitución económica depende de la protección de la esfera privada y la preminencia de la sociedad civil sobre la organización política estatal ${ }^{13}$.

El camino que proponemos seguir para comprender mejor la Constitución económica, empieza por advertir que no se trata de un capítulo autónomo que pueda ser entendido de manera separada de otros principios constitucionales que lo fundan. Mostraremos cómo los principios que orientan el régimen económico, es decir, el principio de subsidiariedad, la libre iniciativa privada, la libertad de empresa, el pluralismo económico, son formaciones que se elaboran sobre la base de otros principios constitucionales que se fundan en el respeto del individuo.

\section{Actividad Económica y Constitución.}

Los términos Constitución económica o capítulo económico de la Constitución nos pueden llevar a pensar que la relación entre el comercio, la empresa y la industria con la Constitución es algo reciente o dependiente de un reconocimiento explícito en el texto constitucional. La experiencia, sin embargo, refleja algo muy distinto. Históricamente, aquellos sujetos al poder político han luchado tenazmente para lograr reducir las intervenciones de las autoridades en sus emprendimientos económicos y la historia del constitucionalismo, ofrece diversos ejemplos tan diversos como Inglaterra, crisol de la experiencia y del pensamiento constitucional (Contreras, 2016, p. 53) y el Perú, aunque la comparación pueda resultar extraña.

Gracias a la Carta Magna ${ }^{14}$ del 1215 - herencia de la edad media a la modernidad y que suele designarse como modelo y origen de las Constituciones liberales (Schmitt, 2011, p. 88) - "los mercaderes serán libres para negociar en general, sin verse expuestos a peajes o impuestos arbitrarios, y prefigura con esa y otras normas el Estado de Derecho"' (Escohotado, 2008, p. 288).

600 años más tarde, en 1810, para gran sorpresa de los españoles, llegaron de las provincias del Perú a las Cortes de Cádiz los señores Vicente Morales Suárez, Blas Ostolaza, Dionisio Inca Yupanqui, Ramón Olaguer Feliú y Antonio Suazo. Estos participaron de los debates constitucionales "con igualdad derechos a los de la Península y con absoluta libertad de palabra y prensa"15. Se dice que la acción más notable de los diputados peruanos fue la proposición de once puntos hecha a las Cortes el 16 de diciembre de 1810.

De estos once puntos, por lo menos siete se encuentran estrechamente relacionados con la libertad o autodeterminación económica. Así, aquellos peruanos alegaron a favor de la libertad de trabajo, comercio e industria, especialmente en agricultura y minería; solicitaron la eliminación de monopolios estatales, la posibilidad de libertad de comercio internacional con el Asia, así como igualdad de opción a empleos entre americanos y europeos (Pareja, 2005, pp. 36-38).

La historia nos enseña que no es necesaria la existencia de un capítulo económico para que economía y Constitución se entrelacen en la realidad. ¿Cómo explicamos esto? Si nuestra concepción de la Constitución es estrecha y pensamos en ésta sólo como un texto organizativo será difícil que lleguemos a apreciar los aspectos más importantes de la Constitución y de la lógica que subyace a esta institución.

\footnotetext{
13 Compartimos esta lectura que, seguramente con justicia, ha sido tildada de solitaria en el escenario nacional. Sin embargo, como reconoce el mismo profesor Hakansson, en el Perú no es ocioso contar con el régimen económico explicito y brindar seguridad jurídica a los agentes económicos en general mediante el reconocimiento de la libre iniciativa privada y del pluralismo económico. De esta forma, "lo que todavía no son capaces de hacer los jueces con sus sentencias para evitar arbitrariedad lo hicieron los constituyentes en las cartas magnas contemporáneas" (Hakansson, 2019, p.478).

14 Según Hume, "la Carta Magna suministra los perfiles de un gobierno legal, con una distribución igualitaria de la justicia y libre disfrute de la propiedad, objetos primarios de la sociedad política humana" (Hume citado por Escohotado, $2008, \mathrm{p}$. 288).

15 Cf. Alayza Paz Soldán citado por Pareja, 2005, p. 36.
} 
Es cierto que existen varias acepciones o maneras de entender la Constitución ${ }^{16}$. Sigamos por un momento el esquema analítico elaborado por el profesor Hakansson que indica que:

una mirada a la teoría constitucional nos ofrece las acepciones más difundidas sobre la idea de Constitución. Las cuales podemos resumir en cuatro: la organización de las instituciones del Estado, la expresión de los factores reales del poder, la norma fundamental del ordenamiento jurídico y un freno el ejercicio del poder para asegurar una esfera de derechos y libertades el ciudadano (Hakansson, 2019, pp. 76-77).

Sin negar la validez de las otras acepciones, consideramos que resulta más fructífero para los fines de nuestro estudio la perspectiva clásica del constitucionalismo. Compartimos, entonces, la conclusión del profesor Hakansson cuando indica que "atendiendo a su origen histórico la Constitución es, digámoslo otra vez, un medio para limitar el poder de los gobernantes que asegura una esfera de derechos y libertades a los ciudadanos. De las tres secciones anteriores, es la única que contiene la finalidad de la Constitución y que no esconde su contenido liberal" (Hakansson, 2019, p. 82). Karl Lowenstein explica que "se deberá considerar como el telos de toda constitución la creación de instituciones para limitar y controlar el poder político. (...) Desde un punto de vista histórico, por tanto, el constitucionalismo, y en general el constitucionalismo moderno, es un producto de la ideología liberal” (Lowenstein, 2018, p. 151) ${ }^{17}$.

Proponemos entonces, como prisma para el estudio de la Constitución económica, una acepción de la Constitución que, menos orientada en su aspecto organizativo y "fundante", entienda el marco constitucional como "una limitación al poder, llevada a cabo por medio del Derecho y afirmando una esfera (la autonomía privada) de derechos y libertades en favor de los ciudadanos". Como explica el profesor Pereira Menaut, "es un rasgo típico del constitucionalismo que el poder, aunque sea legítimo y de la mayoría, este siempre limitado: limited government, gobiernos limitados, que nunca lo puedan todo, y "contrapesados" por unos checks and balances formales o reales, que van desde otras instituciones políticas hasta una sociedad civil autónoma" (Pereira Menaut, 2011, p. 41).

El programa de la ESM depende de una sociedad civil autónoma. El entendimiento de la Constitución como límite del poder ayuda a perfilar una noción de Constitución económica en esa misma línea, como los principios que el Estado no debe transgredir al momento de intervenir en la actividad económica nacional.

\section{La autonomía privada y los derechos fundamentales económicos.}

El principio de autonomía privada se encuentra positivizado en artículo 2.24.A.a. de nuestra Constitución que reza que "nadie esté obligado a hacer lo que la ley no manda ni impedido de hacer lo que no prohíbe". Sobre la base de este principio podemos decir que "de lo que el hombre libre puede presumir es de que, mientras se mantenga dentro de los límites fijados por las leyes, no tiene necesidad de solicitar permiso de nadie ni de obedecer orden alguna" (Hayek, 2014 a, p. 287).

En similar tenor, Raymond Aron enseña que "la idea básica constitutiva de la noción de libertad es la ausencia de arbitrariedad. Cuando se ejerce el poder ateniéndose a las leyes, los individuos gozan de

\footnotetext{
16 Para una clasificación de las principales acepciones, véase Pereira Menaut pp. 37-40.

17 Categórico en esta línea es Leon Duguit que encuentra en la noción de limitación de poder estatal el fundamento mismo del derecho público y postulado base de la civilización. Dice en sus Lecciones:

Hoy debemos estudiar una cuestión extremadamente importante que seguramente le puesto capital el derecho público pues, para hablar con claridad, según se responde la misma con un sí o con un no, existe o no el derecho público. Tienes la de saber si existe una delimitación jurídica lección de listo. Si esta limitación no existe, el Estado puede hacer todo y por ende se sustrae a toda regla de derecho. Para que esté sometido a ésta, hace falta una regla superior al propio Estado, una regla que determine el ámbito de su acción, que fije lo que debe y lo que no puede hacer.

Esta regla existe, es necesario que exista y no se trata de decir que si no existiera habría que inventarla. Poco importa el fundamento que se le dé. Es necesario que exista pues si no existiese no habría la menor seguridad jurídica para las personas; el Estado sería una fuerza y sólo una fuerza y no habría la menor garantía para los individuos contra la arbitrariedad del poder (2011, p. 167).
} 
seguridad". Spinoza advierta la utilidad práctica de este principio cuando declara que "arreglarlo todo con decretos enerva los vicios en vez de corregirlos, pues todo lo no prohibible debe necesariamente ser permitido" (Spinoza citado por Escohotado, 2020, p. 461).

Sería un error, sin embargo, pensar que la autonomía privada la debemos a su mero reconocimiento constitucional. La libertad personal se forja bajo la observancia práctica de la regla del Derecho privado, del efectivo respeto que día a día nos mostramos unos a otros en la convivencia social honrando nuestros acuerdos y respetando la propiedad ajena ${ }^{18}$.

El Derecho privado, que rige las relaciones humanas libres, se debe solo en parte a la organización Estatal -que lo sistematiza y declara en Códigos y leyes-; surge ${ }^{19}$ como consecuencia de las necesidades innatas de la convivencia social de personas independientes. Sus principios fundamentales son, según Hume, las "tres leyes de la justicia": la estabilidad de la posesión, su transmisión por consentimiento y el cumplimiento de las promesas. Duguit, por su parte, explica que dicho sistema funciona a través de la -libertad de contratación, la inviolabilidad de la propiedad y la obligación de indemnizar por el daño infligido a terceros. (Hume citado por Hayek, 2014 b, p. 234).

Del respeto de la autonomía privada se alzan los derechos fundamentales como otra de las columnas del Estado de Derecho. Carl Schmitt explica que ya no es posible entender un Estado Constitucional sin garantías para las libertades fundamentales de los ciudadanos. Estas garantías serían "el reconocimiento de derechos fundamentales, división de poderes y, al menos, una participación del pueblo en el poder legislativo mediante una representación popular" (Schmitt, 2011, p. 78).

Al respecto, Lowenstein señala que:

Entre todos los límites impuestos al poder del Estado se considera que el más eficaz es el reconocimiento jurídico de determinados ámbitos de autodeterminación individual en lo que Leviatán no puede penetrar. El acceso a estas zonas está cerrado a todos los detentadores del poder, al gobierno, el parlamento y, dado que los derechos fundamentales son "inalienables", también al electorado. Estas esferas privadas dentro de las cuales los destinatarios del poder están libres de la intervención estatal, coinciden con lo que se ha venido llamar desde hace 300 años los "derechos del hombre "o "libertades fundamentales". [...] estas garantías fundamentales son el núcleo inviolable del sistema político de la democracia constitucional, rigiendo como principios superiores al orden jurídico positivo, aun cuando no estén formulados en normas constitucionales expresas. En su totalidad, estas libertades fundamentales encarnan la dignidad del hombre (Lowenstein, 2018, p. 390).

Los derechos de autodeterminación económica, que no son otra cosa que una elaboración más elevada del principio general de autonomía privada con énfasis en el plano económico, se encuentra, según Lowenstein, como parte de la triada que conforma, podríamos decir, el "núcleo duro" de los derechos fundamentales, junto con las libertades civiles y políticas:

Suele ser corriente distinguir las libertades enraizadas directamente en la persona -las libertades civiles en sentido propio- de las libertades económicas y políticas. Las fronteras son frecuentemente fluctuantes. En la primera categoría hay que asignar: la protección contra la 18 El célebre jurista alemán F.C. Savigny lo explica así: "el hombre se halla en el centro del universo exterior, y el elemento que le resulta más importante en su entorno es el contacto con los que son de su mismo índole y condición. Ahora bien, si en este contacto han de vivir juntos seres libres que se estimulen mutuamente y no entorpezcan su respectiva evolución, esto sólo es posible mediante el reconocimiento y la aceptación de una frontera invisible dentro de la cual la existencia y actividad de cada individuo tiene un espacio libre y seguro. La regla que traza esta frontera y define este espacio libre es el derecho." (Savigny citado por Hayek, 2014, p.195).

19 Pensar que el derecho puede regir la convivencia social impuesto desde las alturas del poder es, explica Ortega y Gasset, "el más insensato ensayo que se haya hecho de poner la carreta por delante de los bueyes" toda vez que el derecho es "secreción espontanea de la sociedad y no puede ser otra cosa. Querer que el derecho rija las relaciones entre seres que previamente no viven en efectiva sociedad, me parece — y perdóneseme la insolencia — tener una idea bastante confusa y ridícula de lo que el derecho es." (2014, p. 30). 
arbitraria privación de la libertad espacio- llamada, en la tradición inglesa, el derecho de hábeas corpus-, La inviolabilidad del domicilio, la protección contra registros y complicaciones ilegales, la libertad y el secreto de correspondencia y de otros medios de comunicación, la libertad de residencia dentro del territorio nacional y asimismo las posibilidades de libre decisión que se deducen de la individualización de las relaciones familiares. La segunda categoría de las libertades fundamentales abarca todo aquello que cae bajo el concepto de autodeterminación económica: la libertad de la actividad económica en general, la libertad de elección de profesión, la libertad de competencia, la libre disposición sobre la propiedad y la libertad de contrato. Las libertades políticas fundamentales, finalmente, hacen referencia a la participación del individuo en el proceso político (Lowenstein, 2018, p. 391).

La doctrina constitucional orientada a garantizar la impenetrabilidad de la esfera privada y limitación del arbitrio del poder público y privado es el Estado de Derecho ${ }^{20}$. Como dice el profesor Viola, "la competencia natural a deliberar sobre aquello que pertenece a los propios fines, es su vez, la justificación filosófica del principio de subsidiariedad, que por tanto, reingresa en el mismo diseño institucional al cual pertenece la rule of law" (Viola, 2017, p.51).

\section{El Estado de Derecho.}

El gobierno de la Ley y no el arbitrio de los hombres es la mejor garantía para el autogobierno personal. Esto se reconoce también en doctrina nacional, cuando se dice que,

El Estado de Derecho aparece como el servidor de la sociedad, no como su amo. El voluntarismo del gobierno nada vale, lo valioso es la regla objetiva e impersonal. La sumisión del Poder al Derecho y la organización del Estado con miras a proteger los derechos de la persona son las dos notas esenciales del Estado de Derecho" (Ferrero Rebagliati, pp. 86-87).

Hoy en día, hay consenso entre los especialistas en que Estado de Derecho y desarrollo económico son inseparables. Los economistas convienen que la ausencia de la supremacía de la Ley sobre el arbitrio del poder político hace imposible un progreso económico sostenido (Tamanaha, 2004, p. 2). Tanto es así que, en vano, un país buscará financiarse en la arena internacional sin claros esfuerzos para implementar el Estado de Derecho en sus naciones. Esto se justifica sobre la base, ampliamente aceptada, que dicha institución provee de seguridad jurídica para las inversiones, la propiedad, los contratos y las transacciones de mercado en general (Ibid.).

La doctrina del Estado de Derecho, la rule of law o de la supremacía de la Ley, se encuentra en la base de la concepción clásica de la Constitución a la que hemos hecho alusión anteriormente ${ }^{21}$. Lowenstein explica que "el constitucionalismo caracteriza a una sociedad estatal basada en la libertad e igualdad y que funciona como Estado de Derecho" (2018, p. 50).

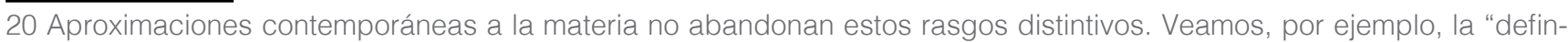
ición mínima" propuesta por el profesor Francesco Viola que se presta del pensador austro-británico -alumno mas no discípulo de Kelsen- F.A. Hayek. Dice Viola que "si queremos identificar en sentido estricto la rule of law, debemos referirnos solamente a los pocos requisitos mínimos para poderse adaptar a los diferentes regímenes jurídicos. Las reglas jurídicas deben reglamentar de un modo ecuánime y general las acciones sociales, Deben poder ser usadas por seres responsables y libres en sus elecciones, deben ser aplicadas imparcialmente por instituciones distintas respecto de aquellas que las producen; y, en general, deben respetar el principio de que ninguno está más allá de la ley (y del derecho). Se trata de requisitos elementales, pero que requieren un desarrollado del sentido del derecho jamás definitivamente conquistado del todo". (2017, p. 21).

21 El núcleo inseparable de Constitucionalismo y el principio de la supremacía del derecho lo explica Fasso rastreándo sus orígenes medievales en Inglaterra: "El principio, típico de la concepción inglesa del derecho según el cual no es el rey, o sea, el Estado, quien hace la ley, pues, al contrario, la ley está por encima del rey -principio que había sido formulado en el siglo XIII por Enrique de Braxton- continúa en el siglo XV para informar el pensamiento jurídico de Inglaterra, determinando la tradición constitucionalista que, nacida de la carta magna de 1215, desembocará en el siglo XVII con la formulación precisa de la doctrina del Estado constitucional y su moderna instauración. [...] Se consolida así, en Inglaterra, la conciencia de la supremacía del derecho sobre todo poder político, de la necesidad observar las reglas del derecho en la vida pública: supremacía de la regla de derecho, cuyo complejo concepto expresan los ingleses con el término rule of law, que es el fundamento del constitucionalismo."
} 
Ahora bien, ¿qué características debe el tener la ley para proteger al individuo? El lector atento se dará cuenta que, si cualquier disposición normativa que provenga del Estado puede ser considerada Ley solo por la fuente de la que proviene, no se podría hablar de ninguna forma de un imperio de la ley ni de límites al poder estatal. Carl Schmitt hace ver que:

Si ley es todo lo que manda determinado hombre o asamblea, sin distingos, una monarquía absoluta será también un Estado de derecho, pues en ella impera la ley, en este caso, igual es la voluntad del rey. También la actual república soviética y la dictadura del proletariado sería un Estado de derecho, pues también hay allí un legislador, y por consiguiente, leyes. Para que el imperio de la ley conserve su conexión con el concepto de Estado de derecho es necesario introducir en el concepto de ley ciertas cualidades que hagan posible la distinción entre una norma jurídica y un simple mandato o voluntad, o una medida.

Imperio de la ley significa, ante todo y en primer término, que el legislador mismo queda vinculada a su propia ley y que su facultad de legislar no es el medio para una dominación arbitraria. La vinculación del legislador a la ley es posible, sin embargo, sólo en tanto que la ley es una norma con ciertas propiedades: rectitud, razonabilidad, justicia, etc. Todas estas propiedades presumen que la ley es una norma general. Un legislador cuyas medidas concretas, órdenes especiales, dispensas y quebrantamientos valgan también como leyes, al igual que sus normaciones generales, no está ligado a su ley en ninguna forma concebible; la "vinculación a la ley" es una expresión sin sentido para aquellos que pueden hacer "leyes" arbitrarias"." (2011, p.197)

Duguit, esboza una explicación similar a la de Schmitt aplicando el famoso principio de legalidad -ampliamente reconocido en nuestro ordenamiento jurídico- en su vertiente material:

Desde el punto de vista material el principio de legalidad consiste en lo siguiente: en un Estado de Derecho ninguna autoridad puede adoptar nunca una decisión individual sino es dentro de los límites fijados por una disposición general, es decir, por una ley en sentido material. Esto es cierto para todos los órganos del Estado, sean cuales sean, lo que incluye a los parlamentos y a los jefes de Estado. Este reconocimiento del principio de legalidad es lo que precisamente distingue a los gobiernos despóticos de los que no lo son. Un gobierno, sea monárquico, aristocrático o democrático, es un gobierno despótico si los órganos de que se compone pueden adoptar decisiones individuales al margen de la regla establecida por una ley general (2011, p. 180).

Reparemos un momento en requisito de la generalidad de la Ley. Otro importante teórico del siglo XX explica con mayor detalle la esclarecedora distinción planteada por Schmitt entre leyes generales y abstractas en oposición a mandatos particulares. Utilizando los términos del griego clásico nomos y thesis, se explica que por nomos entendemos "una regla universal de conducta aplicada a un número no conocido de casos futuros e igualmente a todas las personas que se encuentran en las circunstancias objetivas descritas por la norma, con independencia de los efectos que la observancia de ésta produzca en una situación particular".

En contraste, se emplea el termino thesis "para indicar cualquier norma que sólo sea aplicable a alguien en particular o que sirva a los fines de quien formula las normas. Aunque estas normas pueden ser también generales en distinta medida y referirse a una multiplicidad de casos particulares, se transforman imperceptiblemente de normas en la acepción común del término en órdenes particulares" (Hayek, 2015, p.16).

Conforme la Ley se aleja de la generalidad a la particularidad las chances de que resulte arbitraria aumentan proporcionalmente. Veamos un ejemplo. Pensemos en una norma general, la obligación de cumplir con la palabra empeñada. Más allá de las situaciones de excepción, esta norma no solo aplica de forma general a la gran mayoría de los individuos, además, probablemente nadie, ni aquellos que 
suelen incumplir sus acuerdos, sostendrían que dicha regla debería ser invertida. Por otro lado, no importa a qué se dediquen los contratantes, cuál sea su rubro o los fines que persiguen, la regla aplica a todos por igual22.

Contrastemos esta regla con un reciente proyecto de ley que proponía el control de precios de medicamentos. Primero, sabemos de antemano que la norma no se dirige a la totalidad de actores de la economía, sino solo a aquellos que comercien en el sector de salud.

La norma persigue el fin específico de hacer menos costosos los medicamentos y facilitar el acceso a ellos, aunque esto sea solo en el corto plazo, dado que es bien sabido que estas medidas generan muy prontamente desabastecimiento.

Finalmente, aunque podremos encontrar parte del público contento con la medida, la mayor parte de los afectados por ésta estarán disconformes con la intervención en su esfera de autodeterminación. Finalmente, la regla puede traducirse a una orden directa sobre aquellos que comercian con medicamentos que les prohíbe vender sobre determinado precio ${ }^{23}$.

\section{El orden económico de libre.}

Vivir en una sociedad democrática y libre implica que, para satisfacer nuestras necesidades y perseguir nuestros intereses personales y colectivos requerimos, necesariamente, de la cooperación del prójimo, la que obtenemos través de vínculos mayormente impersonales de reciprocidad, donde cada quien persigue sus propósitos con la colaboración con los demás ${ }^{24}$.

\footnotetext{
22 ¿Es perfecto este orden que surge de la observancia del derecho privado? Sin duda que no. "Terrenal y falible, la justicia instaurada por el desarrollo del comercio alterna con la venalidad y la corrupción, rasgos muy bien conocidos también en el mundo precomercial, aunque añade a ellos un progreso de artes y ciencias". Quizás, lo más importante es que nos obliga como personas a "dejar atrás la compartimentación del mundo en bueno o malo, verdadero o falso, positivo o negativo, oponiendo al dualismo en general algo que ha llegado a realizarse merced del trabajo y la paciencia" (Escohotado, 2020, p. 435)

23 En la realidad, esto es algo similar a imponer la beneficencia obligatoria y la experiencia histórica enseña sin excepción que esta no es la mejor de las ideas. Es una vieja historia que decanta siempre en trágicos desenlaces. Cuenta Escohotado que,
}

"hacia mediados del siglo XIX empezó a considerarse que el derecho era un mero barniz subordinado a imperativos más profundos, que se identificaron con planificar la actividad económica, el ideario político, el servicio de la deidad verdadera, la exaltación de alguna raza y otros ambiciosos proyectos de ingeniería social, presididos todos por la confianza en líderes infalibles. Desprestigiado así el derecho, que es una creación impersonal y sin fines particulares -como el lenguaje, la ciencia o la cultura -, los derechos humanos propiamente dichos (vida libertad, búsqueda autónoma de la felicidad) parecieron demasiado poco, del mismo modo que la idea clásica de la justicia ("no violarás el derecho") pareció demasiado poco también, y se propuso como justicia económica, política, social, racial o teologal. [...]

Por loable que resulte a primera vista el propósito, no deja de ser falaz, banal y tendencioso confundir aspiraciones con garantías. Con gran detalle, el siglo XX enseña que equiparar declaraciones con garantías jurídicas justificó seguir pisoteando la condición humana por el camino más directo, poniendo en lugar del impersonal derecho, decretos de una u otra jefatura. $[\ldots]$.

Hace varias décadas, Isaiah Berlín distinguió derechos civiles negativos y positivos. Los negativos tienen su garante en la burocracia de cada sociedad civil convertido en Estado, y limitan sustancialmente la discrecionalidad de esa burocracia. Los positivos dependen del jerarca ascendido a mesías en cada lugar, y burocratizan la vida hasta extremos inauditos.

Cabe añadir que el derecho como regla de juego puede también considerarse la infraestructura del desarrollo, material o espiritual. Quien lo considere trampa insolidaria aspira a desandar el anarquismo civilizado puesto en boga desde la industrialización, negando su aceptación del azar y la maestría, pero al precio de instar simplismos tan antisociales como la envidia y la barbarie. No hay victimador más idóneo que el victimista, un corredor de desgracias alimentado por amnesia y mala fe" (2015, pp. 109-10)

24 Que vicios privados se traduzcan en beneficios públicos, fue la gran explicación del holandés Bernard Mandeville sobre el orden de mercado en el siglo XVIII: "Al presentar una armonía de conveniencias particulares como origen de la sociedad prospera, Mandeville nunca muestra con precisión como se forma un orden sin previo designio, pero pone fuera duda que así ocurre. Esto anticipa todos los análisis ulteriores basados en procesos de autoorganización, y formula por primera vez el concepto de la división de trabajo. (...) Con el derecho como aliado, la especialización y el interés particular fundan una 
Decimos vínculos libres porque nadie puede obligar al prójimo a ser solidario con su causa y forzarlo a que cubra sus necesidades o las de otro, buscando imponer la beneficencia por la fuerza. Podemos decir que "los privados regulan sus relaciones mediante el contrato, independientemente de la reglamentación pública, y su fuerza vinculante reposa en el principio de reciprocidad" (Kresalja, 2015, p.15).

El reconocimiento de la dignidad humana proscribe forzar al prójimo a ser medio para nuestros fines, sin importar lo altruista de éstos. A diferencia de la beneficencia que es muy deseable, pero voluntaria, Adam Smith observa que la observancia de la justicia no debe ser dejada a la buena voluntad porque "la violación de la justicia es prejuicio, causa un daño real a alguna persona particular por motivos desaprobados por todos". (p.28).

Lo más interesante de esta cuestión, sin embargo, es que el resultado de todas estas transacciones privadas genera un orden de cosas - el mercado- beneficioso por generar oportunidades de actividad económica diversa para la generalidad de las personas. Escohotado denomina estas instituciones, ingeniosamente, los seres del tercer tipo:

No me resisto recordar que los mayores logros conceptuales de aquel periodo fueron precisamente el análisis de entidades que no son ni sujetos volitivos ni objetos inertes, si no seres de un tercer tipo, resultado de concurrir ilimitadas acciones individuales en algún orden no planeado a priori. La mano invisible de Smith, la estructura impersonal que Kant describe como entendimiento humano, el no menos impersonal espíritu de las leyes expuesto por Montesquieu o la matriz lingüística del indoeuropeo intuida por William Jones, zona mediados del siglo XVIII otras tantas evidencias de realidades ni psicológicas ni extra psicológicas.

Estos seres del tercer tipo representan la complejidad propiamente dicha, y ha dejado de parecerme merecedora de explicación teórica otra dinámica que la suya, donde la finalidad está presente en todo momento pero no puede asimilarse a propósitos. Su mera existencia impone ver en lo real algo que se hace a partir de nosotros y a la vez sobre nosotros emancipándonos del simplismo con el que tanto hubieran de luchar los sabios del siglo XVIII. La economía de un país desarrollado, por ejemplo, es algo tan superior a un decreto u otro como el clima; del mismo modo que podemos contribuir a que un territorio se desertice o repueble botánicamente, y a que el intercambio de bienes y servicios se estimule o coarte, no podemos evitar una concatenación autónoma de variables infinitas que en todo momento aplaza la identidad de intenciones y resultados (Escohotado, 2015, p. 120).

Estas incontables transacciones privadas forman un orden regido por las normas del derecho privado que conocemos como economía de mercado. Este proceso de carácter autoorganizativo es blanco de conocidas críticas y caricaturizaciones. Sin embargo, la experiencia histórica ha demostrado las amplias ventajas que conlleva mantener un orden económico libre en contraposición a uno centralmente planificado. Menciona el autor:

El efecto de perseguir cada cual sus proyectos de industria y mejora, redunda demostrablemente en beneficios públicos, mientras subordinar su iniciativa al altruismo decretado por algún salvador providencial provoca desastres públicos igualmente demostrables (Ibid, 2015, p. 335).

Es natural que nos preguntemos cómo es qué, si el Estado no dirige desde arriba la economía, puede ser posible que surja un orden económico. Es necesario distinguir entre una economía particular y el pluralismo económico -reconocido el artículo 60 de la Constitución- que conforma la economía nacional:

Una economía, como en sentido estricto podría definirse una familia, una explotación agrícola o una empresa, consiste en un complejo de actividades a través del cual se destina un sociedad incomparablemente preferible a la construida sobre denuestos altruistas." (Escohotado, 2020, pp. 413-414). 
determinado conjunto de medios, de acuerdo con un plan unitario, a unos cines en competencia según su importancia relativa. El orden de mercado no sirve a semejante orden único de fines. En este sentido, lo que generalmente se define como economía social o nacional no es una única economía sino un sistema de economías conexas entre sí. El orden de mercado tiene en común con la economía en sentido propio algunas características formales, pero no la más importante: sus actividades no están gobernadas por una única escala o jerarquía de fines.

Mientras que una economía propiamente dicha es una organización en el sentido técnico en el que dicho término se define, o sea una o sea una ordenación deliberada del uso de los medios conocidos por un único organismo, el cosmos del mercado no es ni podría ser gobernado por esta única escala de fines; el mismo sirve a los fines separados e inconmensurables de todos sus miembros particulares (Hayek, 2014b, p. 310). 


\section{PARTE II: Economía social de mercado}

\begin{abstract}
Las ideas originales de la Economía Social de Mercado no están basadas en un manifiesto político partidista, sino en concepciones filosóficas respecto del adecuado funcionamiento de un sistema económico y sobre el análisis de distintos órdenes económicos, tanto del presente como del pasado. Esto llevó a la conclusión que una economía impulsada por una sociedad libre era superior a una de corte autoritario, centralizada y dirigida por el poder político. Al mismo tiempo, se proclamó que un orden libre y competitivo era la mejor manera de cumplir con las expectativas de una vida independiente y digna, que ningún sistema colectivo de planificación puede otorgar.
\end{abstract}

Hemos visto, en la primera parte de esta investigación, las instituciones que subyacen a una economía social de mercado. Resumiendo los hallazgos, sin posibilidad de autodeterminación económica garantizada por la observancia del Estado de Derecho- no puede haber un orden social libre o de mercado. Los teóricos y políticos alemanes que se esforzaron por impulsar el establecimiento de un programa económico Constitucional que traslade el control económico del centralismo estatista al proceso autoorganizativo de la sociedad civil y de un mercado más libre sabían esto bien.

Estos pensadores eran plenamente conscientes de que a sus doctrinas económicas subyacían no menos importantes concepciones respecto del individuo, del derecho y de las instituciones sociales en general. Estos son presupuestos fundamentales para que se genere el ecosistema necesario para una economía dinámica que permita mayores oportunidades de trabajo y emprendimiento para la generalidad de las personas y no solo para aquellos favorecidos política o burocráticamente.

Müller-Armack - uno de los principales exponentes de la economía social de mercado explica - que:

el objetivo debe ser una economía de mercado con protecciones sociales que se ajusten a las reglas del mercado. Es probable que el orden de libre mercado logre una tasa de productividad mucho más alta que cualquier economía intervencionista. Esta creciente riqueza permitirá a la sociedad llevar a cabo sus deberes sociales y morales. Al salvaguardar el aparato de intercambio y la libertad comercial, la economía de mercado permanece dentro de los límites de lo posible y evita la situación tragicómica del intervencionismo que combina promesas cada vez mayores con un nivel de vida en deterioro (Zweig, 1980, p. 34).

La necesidad de una economía libre que haga viable la "legislación social" también fue advertido por Schumpeter que dice que "la técnica y la atmosfera de la lucha por la legislación social oscurecen dos hechos que de otra forma, resultarían obvios: de un lado, parte de esta legislación presupone un previo éxito capitalista (en otras palabras, presupone una riqueza que tiene que haber sido previamente creada por la empresa), y de otro lado, gran parte de las medidas desarrolladas y generalizadas por la legislación social surgió de la acción previa del mismo estrato capitalista. 
Por supuesto, ambos hechos hay que añadirlos a la suma total de los logros del capitalismo. Si el sistema siguiese su curso... se cumplirían de forma automática o podrían cumplirse sin interferir de forma apreciable en el funcionamiento del régimen capitalista. Entonces, solo las prestaciones en gran escala para los parados serían no solo una carga tolerable, sino también ligera. (Schumpeter, 2015a, p. 146).

Finalmente, prestemos atención a la advertencia de Müller-Armack respecto de otra confusión regular en nuestro medio:

La Economía Social de Mercado no es una mezcla de Capitalismo y Socialismo. Se atrevió a lograr, sobre la base de un sistema de libre competencia, el progreso social y económico al mismo tiempo. Por un lado, está la libertad de competencia con la garantía de la propiedad privada, de actuar sin coacción y participar en el crecimiento de la riqueza. Esta eficiencia económica está entrelazada en la Economía Social de Mercado con el progreso social, la superestructura sociológica que produce para nuestra sociedad las necesidades espirituales y morales (Zweig, 1980, pp. 33-34.).

La economía social de mercado es mejor entendida como un conjunto de ideas guía que busca establecer un marco social y jurídico para la producción eficiente de bienes materiales y para garantizar la libertad personal o autonomía privada en un ambiente social balanceado capaz de adaptarse a las siempre cambiantes circunstancias, eso sí, basado en principio en el rechazo de la dirección central, los controles colectivos y las interferencias discrecionales y arbitrarias (Zweig, 1980, pp. 7-8).

La idea guía según la cual en la ordenación de nuestros asuntos económicos debemos hacer todo el uso posible de las fuerzas libres de la sociedad civil y recurrir lo menos posible a la coacción estatal, permite una infinita variedad de aplicaciones y de actuaciones por parte del Estado (Hayek, 2017, p.105).

\section{Origen histórico: las reformas de Erhard.}

En el año 1948, Alemania Occidental era un país en ruinas, con una población que pasaba hambre, sin viviendas y como la incertidumbre respecto del futuro político y económico del país era enorme la iniciativa privada se encontraba casi paralizada (Erhard, 2010, p. 12). En la República Federal Alemana se gestaba por aquel entonces un acontecimiento político-económico que sería de trascendental importancia no solo en Alemania, sino también para el mundo. Esto iba a suponer el cambio abrupto de una economía planificada centrada en la supremacía del Estado, con intervenciones estatales ilimitadas en el sector privado, a un sistema de economía de mercado y libre empresa (Ibid., 2010, p. 11). Ahora bien ¿qué hicieron los alemanes para encausarse en la senda del desarrollo económico?

El profesor emérito de la Universidad de Colonia - Jürgen Doenges - sostiene que cuando se trata de solucionar una crisis económica de fondo siempre hay dos opciones: estrategias graduales o estrategias de choque. Dice también que la realidad demuestra que los gobiernos temerosos de cosechar impopularidad tienden no solo a ser gradualistas sino también a orientarse a corto plazo y cambiar de rumbo cuantas veces sea necesario si resulta rentable a efectos electoralistas (Ibid., 2010, p.12).

Ludwig Erhard, el entonces Director General de Economía de las Zonas de ocupación estadounidense y británica hizo todo lo contrario a lo que hacen los líderes de corte populista. Optó por un tratamiento de choque y lo llevó hasta las últimas consecuencias, ignorando las objeciones que le hacían nada menos que el Alto Comisario norteamericano, empresarios, sindicatos y profesores universitarios de tendencias anti-mercado (Ibid., 2010, p.12). 
El 20 de junio de 1948, Erhard dio de baja a la entonces moneda oficial alemana e introdujo el Deutsche Mark. Además, abolió de forma abrupta los controles de producción y fijación de precios que había sido promulgado por la administración militar. El curso de acción de Erhard se podría explicar como el pasó -en el menor tiempo posible- de una economía planificada a una economía de mercado, de una economía desvinculada del comercio internacional a otra que iría a integrarse en el mundo, de una economía inflacionaria a otra en la que la estabilidad del nivel de precios sería un objetivo macroeconómico de primer orden (Ibid., 2010, p.13).

Explica Wilhelm Röpke que la reforma alemana del 1948 constaba de dos partes, podríamos decir que una macroeconómica y la otra microeconómica. Por un lado, se buscaba lograr el fin de la inflación y la estabilidad monetaria. Del otro, la supresión del aparato coactivo económico impuesto sobre la sociedad (control de precios, cantidad de mercancías, racionamientos, etc.), para volver a la libertad de los mercados, precios libres, libre competencia, libertad de consumo y libertad de iniciativa empresarial (Röpke, 2007, p. 257).

Es importante destacar que Erhard -como individuo- tenía la convicción que el motor de la economía tenía que ser la inversión privada. Desconfiaba de un Estado que quisiera abarcar mucho y veía en el mercado y la competencia la fuerza generadora del progreso económico. Sobre la base de esas convicciones, Erhard apostó por la creación de una nueva moneda y un sistema central bancario con autonomía frente al gobierno y con el claro principio rector de velar por la estabilidad monetaria. Erhard preparó así el terreno y levantó las estructuras fundamentales para que pudiera surgir la economía social de mercado en Alemania Occidental - la RFA- en la que por razón de principio se respetarían la libertad contractual y la autonomía de las organizaciones sociales y en la que el Estado asume el compromiso de corregir dentro de ciertos límites, los resultados distributivos producidos por el mercado.

Respecto del programa económico de Erhard, explica Escohotado que,

En contraste con los programas de la RDA, el lanzado por Erhard en junio de 1948 se propuso establecer cuanto antes una realimentación a través del consumo, simultaneando recortes drásticos en la presión fiscal, retorno al librecambio y una nueva moneda, mientras la RFA ultimaba su fundación cómo Estado Social Derecho (Sozialrechstsstaat), prometiéndose tener el más avanzado sistema de seguros, jubilaciones, servicios públicos y respeto por el medio ambiente. Con todo, lo inmediato era capitalizarse sin hipotecas, reinvirtiendo en el tejido de negocio tanto las ventas del sector privado como un alto porcentaje de las fiscales, no abrumadas ya por la factura de control totalitario, sin olvidar -en palabras de Erhard- qué "cuánto más libre más social es un economía", y acceder al socialismo pasa por asegurar el liberalismo." (Escohotado, 2016, p. 521).

El éxito fue tan arrollador y extraordinario y el tránsito de la pobreza y la desesperación a la prosperidad y a una actividad económica febril tan súbito, que en todas partes comenzó a hablarse del "milagro económico alemán". Sin embargo, desde el punto de vista económico el resurgimiento alemán no fue ningún milagro. El único milagro fue haber podido lograr los consensos políticos y sociales para volver al buen sentido de la economía de mercado y la disciplina monetaria (Röpke, 2007, p. 256) ${ }^{25}$.

Ahora bien, el caso de Alemania de la posguerra es particularmente interesante por el contraste de sistemas que nos permite realizar. Hay que tener presente que luego de la segunda guerra mundial Alemania fue separada en dos partes y a pesar que los pobladores de ambos países compartían 
la misma historia, cultura, idioma, costumbres y mentalidad, los logros económicos en las décadas siguientes a la guerra fueron muy dispares al este y al oeste del famoso telón de acero.

Si bien, por un lado, la República Federal - que se guía por principios de libertad económica - florece para ser un ejemplo que llegarían a seguir muchos países de oriente y occidente, por otro lado, la República Democrática, es decir, Alemania Oriental, sufría de ineficacia y carencias por la ausencia de estos principios, por lo que era necesario mantener un muro custodiado por hombres armados y sin reservas para matar con la finalidad de que sus habitantes no se escapan del paraíso soviético (Röpke, 1989, p. 12).

Con esta experiencia histórica, Alemania demostró de forma empírica, que por un lado, el sistema colectivista o intervencionista no solo presupone la ausencia de libertad política y cultural, sino además que acarrea el desorden económico, el despilfarro y un bajo nivel de vida, y por el otro, que el sistema diametralmente opuesto, el de economía de mercado, "no solo constituye pilar esencial y condición fundamental de la libertad política y cultural, sino, al mismo tiempo, el camino para el orden económico más eficiente y la mejora del bienestar de la población." (ibid. p.255).

\section{Principios constitutivos de la ESM.}

Ahora bien, entrando a lo que son los principios constitutivos de la economía social de mercado, sigamos la explicación de Walter Eucken ${ }^{26}$-uno de los principales teóricos de la materia, que destaca seis principios que articulan de forma interdependiente la política, la economía y el derecho: los seis principios son: sistema de precios libres; moneda estable; mercados abiertos y competitivos; políticas económicas de largo plazo, inviolabilidad de la propiedad y de la libertad contractual. Pasemos a revisar someramente en qué consisten fundamentalmente estos principios:

1. El mantenimiento de un sistema de precios que funcione correctamente, libre de controles, debe ser un objetivo principal. Este principio es primordial y debe respetarse en todas las esferas de la política económica, por lo que no debe haber control ni subvención de precios y salarios, interferencia con las tasas de interés, controles de importación, etc. Está condenada la política económica que no respeta el mecanismo autorregulador de los precios. Es el centro estratégico que domina el conjunto.

La función de los precios consiste única y exclusivamente en ser el mecanismo a través del cual, los individuos descubren las fluctuaciones y cambios de la demanda y la oferta, actuales y futuros, interiores y exteriores. Solo de esta forma de esta forma la asignación de recursos puede hacerse optima. Las correcciones sociales distributivas que se puedan considerar pertinentes deben llevarse a cabo a través de transferencias directas y abiertas, financiadas mediante recaudaciones impositivas. Esta división de funciones garantiza la transparencia de la política socialmente redistributiva.

Hay consenso entre los especialistas $-\mathrm{y}$ esto se ha podido ver a raíz de las últimas leyes dictadas por el Congreso en materia económica- que el sistema de precios libres debe excluir por cuestión de principio el control de precios de y cuantías. Esto se debe, por el simple hecho de que dichos controles jamás pueden manejarse con arreglo a normas prestablecidas, siendo, por el contrario, de índole discrecional y arbitraria. "Dichas facultades implican permitir al gobernante que decida por sí y ante sí qué deba producirse, por quién y para quién." (Hayek, 2014, p. 311).

Finalmente, como indica Schumpeter "precio justo es precio competitivo. Resulta perfectamente justo que los mercaderes logren ganancias mientras sea pagando y 
aceptando los precios del mercado. Si sufren pérdidas, será mala suerte o una penalidad por incompetencia. Pero esto siempre que ganancia o pérdida resulte del funcionamiento no obstaculizado del mecanismo mercantil; no si deriva, por ejemplo, de la fijación del precio por la autoridad pública o conglomerados monopolísticos." (Escohotado, 2018, p. 364).

2. Una moneda estable es indispensable para establecer el orden competitivo. La inflación abierta o reprimida distorsiona la función de asignación de precios y falsifica todo cálculo económico.

3. Los mercados abiertos o competitivos son otra condición previa para el tipo de competencia propugnada por Eucken. Las modernas concentraciones de poder estatales y privadas, han inventado innumerables instrumentos para cerrar la oferta y la demanda y obstaculizar la competencia, p.ej., concesión de licencias de inversión, monopolios estatales, uso indebido de derechos de patente, etc.

Eucken advierte que el Estado debe proveer un marco dentro del cual el mercado pueda operar competitivamente ejerciendo su función anónima de asignación de funciones y bienes.

4. Las políticas económicas deben mantenerse de forma constante y deben indicar un camino a seguir a largo plazo. La inestabilidad de las políticas económicas - stop go- afecta la toma de decisiones del emprendedor, confunde sus expectativas y por lo tanto reduce los incentivos para la inversión privada.

En un Estado de Derecho el Estado debe garantizar una estructura legal permanente compuesta de normas generales predecibles en su interpretación por la administración y los tribunales, bajo el amparo de las cuales los actores sociales pueden decidir libremente el uso de sus recursos y los fines que persiguen, de esta forma la actividad productiva será guiada por las decisiones de los individuos que conformas la sociedad.

5. La propiedad privada y la asunción de riesgos privados son esenciales para el funcionamiento de un mercado libre. La propiedad colectiva de grandes sectores de la economía seguramente conducirá a inversiones antieconómicas y de baja eficiencia, mala asignación de los medios de producción y preservación de unidades comercialmente obsoletas.

En caso que se dé la propiedad estatal, debe obedecer las reglas del mercado y no enfrentarse a las fuerzas del mercado a través de subsidios abiertos u ocultos, perpetuando la ineficiencia, el exceso de personal y la ignorancia de los entornos cambiantes de la demanda, etc.

6. La libertad de contratación es otra condición previa para el funcionamiento de la competencia, aunque debe evitarse que se utilice indebidamente hacia agrupaciones monopolísticas.

\section{Consideraciones finales.}

Pasa de ser más de una coincidencia, que 40 años después del milagro económico Alemán, en el Perú adoptamos la economía social mercado como sistema económico, en aquel entonces un país muy diferente al que conocemos hoy día. Al igual que en Alemania, venia de un modelo económico centralista que había generado una de las inflaciones más grandes que ha visto el mundo occidental. En Perú, teníamos un régimen fallido de industrialización por sustitución de exportaciones que había convertido la participación del país en el comercio internacional en casi inexistente y, donde existía 
una carencia generalizada de los bienes de subsistencia más básicos. En pocas palabras una época apocalíptica en términos económicos, como destruida estaba en 1948 la economía alemana.

Precisamente por el hecho de haber sido exitoso en el Perú, el programa de la economía de mercado sufre un especial peligro y no debemos pensar que la obviedad de sus resultados son motivo suficiente para que el sistema persista. Lo cierto es que es bien sabido que la economía de mercado usualmente "fracasa triunfando", en palabras de Hayek, i.e., que el éxito real del mercado es la causa de su decadencia (Hayek, 2017, p106).

Uno vez que las, sociedades llegan al estado de bienestar material que solo es posible bajo la superestructura institucional de una economía libre, encuentran los límites fijados por esta superestructura como un fastidio para la consecución de sus objetivos. Con frecuencia los políticos usan como chivo expiatorio al sistema económico por los fracasos de gestión que nada tienen que ver con la tarea de producción de bienestar material del sistema de mercado.

El sistema de economía social de mercado tiene mecanismos para ayudar a los menos privilegiados pero estos mecanismos no consisten en manipular el sistema de precios y sacrificar el buen funcionamiento del mercado que sirve al bienestar general. Como señala Alexander Rüstow, uno de sus fundadores, los valores éticos, cultural y humanos en general son más importantes que la economía, sin embargo, la economía es lo que prepara el terreno para que estos valores se puedan desenvolver (Rüstow citado por Zweig, 1980, p18).

En efecto, es difícil salvar a una civilización - sostiene Ortega y Gasset-cuando le ha llegado la hora de caer bajo el poder de los demagogos, "grandes estranguladores de civilizaciones". Respecto de la esencia de la demagogia, señala que esta consiste en la irresponsabilidad del demagogo ante las ideas mismas que maneja y que él no ha creado, sino recibido de los mismos creadores (2014, p. 54). En otras palabras, el demagogo combina, mezcla y presenta las ideas como le viene en gana y suenen mejor para la tribuna. No parece controversial sostener la tesis que una amenaza siempre latente para el Perú y para la prosperidad económica de su sociedad civil consiste en la manipulación de la economía por las autoridades. 


\section{Bibliografía:}

Aron, R. (2013) Las etapas del pensamiento sociológico (2 $2^{\mathrm{a}}$ ed.) Editorial Tecnos.

Contreras, J.F. (2016) La Filosofía del Derecho en la Historia. (2a ed.) Editorial Tecnos.

Duguit, L. (2011). Lecciones de Derecho público general. Impartidas en la Facultad de Derecho de la Universidad egipcia durante los meses de enero, febrero y marzo de 1926. Marcial Pons.

Erhard, L. (2010) Bienestar para todos (2ª ed.) Unión Editorial.

Escohotado, A.:

- (2020) Los Enemigos del Comercio. Una historial moral de la propiedad. Tomo I. (12 ${ }^{\mathrm{a}}$ ed.). Espasa ( $1^{\text {a }}$ ed. 2008).

- (2018) Los Enemigos del Comercio. Una historial moral de la propiedad. Tomo II. Espasa (1 $1^{\mathrm{a}} \mathrm{ed}$. 2013).

- $\quad$ (2016) Los Enemigos del Comercio. Una historial moral de la propiedad. Tomo III. (5ª ed.). Espasa ( $1^{\text {a }}$ ed. 2016).

- $\quad$ (2015) Frente al miedo. Ed. Guillermo Herranz. Página Indómita.

Ferrero Rebagliati. R. (2003) Obras Completas. Tomo V. El Liberalismo Peruano. Universidad de Lima.

Loewenstein, K. (2018) Teoría de la Constitución. Ariel (1ª ed. 1965).

Hakansson Nieto, C. (2019) Curso de Derecho Constitucional (3ª ed.). Palestra Editores.

Hayek. F.A.:

- (2014a) Fundamentos de la Libertad. Unión Editorial (9a ed.).

- (2014b) Derecho, Legislación y Libertad. Unión Editorial (2ª ed.).

- (2017) Camino de Servidumbre. Unión Editorial (2ª ed.).

Ortega y Gasset, J. (2014) La rebelión de las masas y otros ensayos. Alianza Editorial.

Pareja Paz-Soldán, J. (2005) Historia de las Constituciones Nacionales (1812-1979). PUCP Fondo Editorial.

Pereira Menaut, A-C (2011) En Defensa de la Constitución. Palestra Editores.

Röpke, W. (2007) La Teoría de la Economía (5ª ed.) Unión Editorial.

Schmitt, C. (2011) Teoría de la Constitución. Alianza Editorial.

Schumpeter, A.:

- (2015a) Capitalismo, socialismo y democracia. Volumen I. Página Indómita.

- (2015b) Capitalismo, socialismo y democracia. Volumen II. Página Indómita.

Smith, A. (1982) The Theory of Moral Sentiment. Liberty Fund.

Tamanaha, B.Z. (2004) On the Rule of Law. History, politics, theory. Cambridge University Press.

Ugarte del Pino (1978) Historial de las Constituciones del Perú. Editorial Andina.

Vignolo, O. (2019) La Dogmática del Principio de Subsidariedad Horizontal. Palestra Editores.

Viola, F. (2017) Rule of Law. El gobierno de la ley, ayer y hoy. Palestra Editores.

Zweig, K. (1980) The Origins of the German Social Market Economy. Adam Smith Institute. 


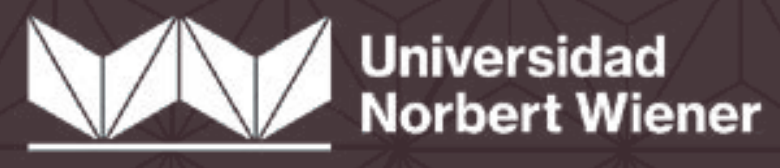

